\title{
O gênero Rhynchosia Lour. (Leguminosae, Papilionoideae) em Mato Grosso do Sul, Brasil
}

\author{
Ana Cristina de Meira Cristaldo ${ }^{1,2}$, Arnildo Pott ${ }^{1}$ \& Ângela Lúcia Bagnatori Sartori ${ }^{1}$ \\ ${ }^{1}$ Laboratório de Botânica, Programa de Pós-graduação em Biologia Vegetal, Centro de Ciências Biológicas \\ e da Saúde - CCBS, Universidade Federal de Mato Grosso do Sul-UFMS, CP 549, CEP 79070-900, \\ Campo Grande, MS, Brasil. www.ufms.br \\ ${ }^{2}$ Autor para correspondência: Ana Cristina de Meira Cristaldo, e-mail: accristaldo@gmail.com
}

CRISTALDO, A.C.M., POTT, A. \& SARTORI, A.L.B. The genus Rhynchosia Lour. (Leguminosae, Papilionoideae) in Mato Grosso do Sul State, Brazil. Biota Neotrop. 12(4): http://www.biotaneotropica.org. br/v12n4/en/abstract?taxonomic-review+bn00812042012

\begin{abstract}
Rhynchosia Lour. is a pantropical genus with 230 species, mainly distributed in the neotropics considered the center of diversity of the group. It is philogenetically related to the genus Eriosema (DC.) Rchb., from which it differs mainly through morphological characters. In Mato Grosso do Sul it is represented by eight taxa: Rhynchosia balansae Micheli var. balansae, $R$. balansae var. psilantha Fortunato, $R$. clausseni Benth., $R$. corylifolia Mart. ex Benth., R. edulis Griseb., R. leucophylla Benth., R. melanocarpa Grear and R. minima (L.) DC. The current study presents identification key, descriptions, comments, illustrations, data on geographic distribution and habitat preference of each taxon.
\end{abstract}

Keywords: Fabaceae, flora, Neotropics, Phaseoleae, plant taxonomy.

CRISTALDO, A.C.M., POTT, A. \& SARTORI, A.L.B. O gênero Rhynchosia Lour. (Leguminosae, Papilionoideae) em Mato Grosso do Sul, Brasil. Biota Neotrop. 12(4): http://www.biotaneotropica.org.br/ v12n4/pt/abstract?taxonomic-review+bn00812042012

Resumo: Rhynchosia, gênero pantropical, é constituído por 230 espécies distribuídas principalmente nos neotrópicos, considerado o centro de diversidade do grupo. Está relacionado filogeneticamente com o gênero Eriosema (DC.) Rchb., do qual se diferencia principalmente por características morfológicas. Em Mato Grosso do Sul está representado por oito táxons: Rhynchosia balansae Micheli var. balansae, $R$. balansae var. psilantha Fortunato, R. clausseni Benth., R. corylifolia Mart. ex Benth., R. edulis Griseb., R. leucophylla Benth., $R$. melanocarpa Grear e $R$. minima (L.) DC. O presente estudo apresenta chave de identificação, descrições, comentários, ilustrações, dados de distribuição geográfica e dos ambientes preferenciais de cada táxon.

Palavras-chave: Fabaceae, flora, Neotrópicos, Phaseoleae, taxonomia vegetal. 


\section{Introdução}

Rhynchosia Lour. pertence à subtribo Cajaninae Benth. (Lackey 1981), composta por 13 gêneros, dos quais apenas Rhynchosia e Eriosema (DC.) Rchb. ocorrem nos trópicos e subtrópicos de ambos os hemisférios (Grear 1978, Miotto 1988). Os hábitos de crescimento, variáveis nos membros de Rhynchosia, aliados à morfologia do hilo da semente e o comprimento do pecíolo possibilitam a sua diferenciação de Eriosema (Grear 1970), ambos relacionados filogeneticamente (Fortunato 2000, Schrire 2005).

De distribuição pantropical, Rhynchosia é constituído por 230 espécies, das quais 55 são endêmicas dos neotrópicos, considerado o centro de diversidade do grupo (Grear 1978, Schrire 2005). No Brasil, os estudos mais abrangentes sobre Rhynchosia consistem na Flora Brasiliensis (Bentham 1859), com o registro de 10 espécies, na publicação de Grear (1978), com 18 citações, e na lista da Flora do Brasil com 19 espécies (Fortunato 2012). Dados pertinentes a Rhynchosia encontram-se dispersos em estudos de floras regionais sobre a Bahia (Lewis 1987); inventários florísticos no Cerrado (Sano et al. 2008), no Chaco (Nunes 2006), no Pantanal (Pott \& Pott 1994, 1999), além de tratamentos florístico-taxonômicos mais específicos realizados para o Rio Grande do Sul (Miotto 1988), Paraná e Santa Catarina (Rogalski \& Miotto 2011) e São Paulo (S.T.S., Miotto, dados não publicados) com informações mais precisas sobre a biologia dos integrantes do grupo. Para Mato Grosso do Sul são referidas quatro espécies de Rhynchosia mencionadas por Grear (1978) e sete espécies por Dubs (1998), em uma listagem compilada a partir de dados de herbários nacionais e estrangeiros.

O presente estudo teve como objetivos realizar um levantamento das espécies de Rhynchosia ocorrentes no Mato Grosso do Sul, fornecer descrições, ilustrações, chaves de identificação e comentários taxonômicos, além de dados referentes à distribuição geográfica, ambientes preferenciais, floração e frutificação.

\section{Material e Métodos}

O estudo foi baseado em revisão bibliográfica, na análise morfológica de caracteres vegetativos e reprodutivos de espécimes da flora sul-mato-grossense, depositados nos herbários CGMS, COR, HRCB, HUEFS, IBGE, MBM, PAMG, RB, R e SP, nas informações das etiquetas das exsicatas, em bibliografia especializada e em coletas adicionais, realizadas nas regiões central e oeste do estado de Mato Grosso do Sul. As siglas dos herbários citados estão de acordo com Thiers (2012). Os espécimes coletados foram herborizados conforme padrões usuais e depositados no herbário CGMS (UFMS).

Para a identificação dos táxons foram utilizadas chaves de identificação, descrições taxonômicas e, quando possível, a comparação com a fotografia do material-tipo. Os táxons foram tratados em categoria específica e infraespecífica, e suas descrições incluíram a amplitude de variação morfológica observada nos espécimes de Mato Grosso do Sul.

A terminologia utilizada para indumento e morfologia das estruturas vegetativas e reprodutivas foi baseada em Font Quer (1953), Radford et al. (1974), Rizzini (1977), Harris \& Harris (1994), Stearn (2004) e Gonçalves \& Lorenzi (2007). A classificação do hábito e das esculturas das asas encontra-se de acordo com Guedes-Bruni et al. (2002) e Stirton (1981), respectivamente.

As ilustrações das estruturas florais, estípulas e folíolos foram confeccionados por meio de material herborizado e/ou hidratado, com o auxílio de um estereomicroscópio.

Informações sobre distribuição geográfica e hábitat foram obtidas consultando-se bibliografia especializada, dados contidos nas etiquetas das exsicatas e em observações de campo. A definição dos ambientes de ocorrência está de acordo com IBGE (Instituto... 1992) e seus equivalentes regionais de acordo com Pott \& Pott $(1994,2003)$ e Ribeiro \& Walter (1998). O termo vegetação secundária refere-se às áreas em regeneração e o termo áreas perturbadas, a ambientes modificados por ação antrópica.

\section{Resultados e Discussão}

Em Mato Grosso do Sul foram confirmados oito táxons de Rhynchosia, o que corrobora em parte as informações de Dubs (1998) para o Estado, pois não foi confirmada a ocorrência de $R$. phaseoloides (Sw.) DC. Rhynchosia balansae Micheli é representada, além da variedade típica, pela variedade $R$. balansae var. psilantha Fortunato, cuja distribuição é restrita à parte oeste do Estado. No Brasil é o único registro de sua ocorrência.

Os táxons registrados principalmente em fisionomias de Cerrado também foram encontrados em bordas de florestas semidecíduas, matas ciliares e em áreas degradadas. Destacam-se aqui $R$. edulis e $R$. minima, únicas representantes do gênero em área de Savana Estépica Arborizada e Florestada, respectivamente Chaco arborizado e florestado.

Como características diagnósticas do grupo destacaram-se a presença de glândulas puntiformes principalmente na superfície abaxial dos folíolos e estruturas florais, o hábito de crescimento subarbustivo ou volúvel, semente com hilo oblongo ou elíptico e funículo inserido no centro do hilo. Rhynchosia edulis é a única que possui o hilo alongado e funículo inserido na porção apical do hilo como em Eriosema.

\section{Rhynchosia Lour., Fl. Cochinch. 425, 460. 1790}

Trepadeiras, ervas ou subarbustos, eretos, procumbentes, prostrados ou volúveis, geralmente com xilopódio. Caules geralmente canaliculados ou sulcados longitudinalmente nas porções apicais; tricomas glandulares de base bulbosa e/ou glândulas puntiformes amarelas, castanhas, pretas ou esverdeadas, presentes; indumento amarelado ou alvacento, tomentoso, viloso, seríceo ou hirsuto. Folhas pinado-trifolioladas, buladas ou não, glândulas puntiformes amarelas e/ou tricomas glandulares de base bulbosa presentes, reticuladas com nervuras proeminentes na face abaxial; com pecíolos e ráquis foliar desenvolvidos, raro subsésseis, ventralmente canaliculados, os folíolos laterais subsésseis, apenas com pulvínulos; estípulas 2, livres, opositifólias, estriadas longitudinalmente; estipelas geralmente presentes. Racemos axilares (simples ou panículas) ou terminais (corimbiformes), laxos ou congestos, mais longos que as folhas; brácteas cimbiformes, caducas; bractéolas nulas. Cálice campanulado, 5 lacínios livres, estreito-triangulares, acuminados, carenal maior que os demais, vexilar fundido parcialmente ao lacínio lateral. Corola amarela, às vezes estandarte, asas e pétalas da quilha estriadas de vermelho ou vináceo; estandarte obovado, pubescente e glanduloso, 2 aurículas inflexas, face interna com calosidades na porção inferior; asas estreitas, elípticas, oblongas ou obovadas, por vezes assimétricas, auriculadas, ápice glabro ou pubérulo e glanduloso, esculturas lamelares nas regiões mediana, ínfero-mediana e basal; pétalas da quilha falciformes, cuculadas na região mediana ou basal, glabras ou ápice pubérulo e glanduloso. Estames 10, diadelfos, glabros, vexilar geniculado na base, persistentes no fruto; anteras dorsifixas, rimosas, oblongas ou elípticas, uniformes em tamanho. Ovário elíptico, ovado ou lanceolado, subséssil, geralmente disco anelar na base, seríceo, biovulado; estilete filiforme, levemente encurvado e inflado no ápice, glabro ou seríceo na base; estigma capitado. Legumes oblongos ou elípticos, retos ou constrictos entre as sementes, mucronados, tomentosos ou seríceos; cálice e estames presentes até a maturação. Sementes 2, suborbiculares a oblongas, uniformes, marrons, marromclaras, marrom-avermelhadas, marrom-vináceas, marmoreadas ou 
bicolores; hilo elíptico ou oblongo; funículo geralmente inserido no centro do hilo.

\section{Chave para a identificação das espécies de Rhynchosia ocorrentes em Mato Grosso do Sul}

1. Plantas trepadeiras

2. Glândulas puntiformes amarelas presentes em ambas as faces dos folíolos, tricomas glandulares de base bulbosa ausentes, legumes falcados, não constrictos entre as sementes... 8. R. minima

2'. Glândulas puntiformes amarelas, castanhas ou esverdeadas presentes apenas na face abaxial dos folíolos, tricomas glandulares de base bulbosa presentes em toda a planta, legumes retos, constrictos ou não entre as sementes.

3. Legumes oblongos, constrictos entre as sementes, vináceos ou preto-vináceos, sementes bicolores (pretas ou marrom-escuras com a área ao redor do hilo vermelha), funículo inserido na porção central do hilo; em espécimes herborizados, glândulas puntiformes amarelas presentes nos folíolos ou em partes florais......... 7. R. melanocarpa

3'. Legumes oblongo-elípticos, não constrictos entre as sementes, marrons, sementes marrons geralmente marmoreadas, funículo inserido na porção apical do hilo; em espécimes herborizados, glândulas puntiformes castanhas, pretas ou esverdeadas presentes nos folíolos ou em partes florais

5. R. edulis

1'. Plantas não trepadeiras

4. Ervas ou subarbustos prostrados

5. Racemos corimbiformes, legume com glândulas puntiformes amarelas e tricomas glandulares de base bulbosa presentes.

4. $R$. corylifolia

5'. Racemos ou panículas laxifloros, legume com glândulas puntiformes amarelas presentes e tricomas glandulares de base bulbosa ausentes............2. R. balansae var. psilantha

4'. Ervas ou subarbustos eretos, se volúveis, apenas nos ramos apicais

6. Face abaxial dos folíolos argênteo-velutina, tomentosa, denso-serícea, glândulas puntiformes amarelas ausentes na face adaxial dos folíolos.

.6. R. leucophylla

6'. Face abaxial dos folíolos alvo-tomentosa, vilosa, esparsopubescente, esparso-hirsuta, glândulas puntiformes amarelas presentes na face adaxial dos folíolos...............7 7. Racemos densifloros, com 18-47 flores por inflorescência..................... R. balansae var. balansae

7'. Racemos corimbiformes, com 3-6 flores por inflorescência. 3. R. clausseni

\section{Rhynchosia balansae Micheli var. balansae, Mém. Soc.} Phys. Genève 28(7): 31.1883 (Figura 1)

Subarbustos eretos, procumbentes, raro ápices volúveis, 0,5-1 m alt.; ramos alvacentos, esparso-tomentosos, tomentosos, vilosos nos ramos apicais, pubérulos na base, tricomas glandulares de base bulbosa ausentes, glândulas puntiformes amarelas presentes. Estípulas caducas, ovadas ou triangulares, base truncada, côncava, ápice acuminado, externamente alvo-tomentosas, vilosas, glândulas puntiformes amarelas esparsas, internamente glabras, 2,9-6,2 $\times$ 1,3-2,7 mm; um par de estipelas filiformes ou setiformes na base do folíolo apical 0,3-1,5 mm compr., um par setiforme nos folíolos laterais, 1,3-1,7 mm compr., tomentosas. Pecíolos 1,6-5 cm compr., ráquis foliar 7,4-11,9 cm compr., tomentosos, vilosos, glândulas puntiformes amarelas ausentes. Folíolos discolores, bulados ou bulados apenas nas bordas, face adaxial alvo-pubescente, esparso- vilosa, face abaxial alvo-tomentosa, vilosa; glândulas puntiformes amarelas presentes em ambas as faces, abundantes na face abaxial; folíolos apicais elípticos, estreito-elípticos, largo-elípticos, obovados ou suborbiculares, 4,4-7,7 × 1,3-4,1 cm; laterais assimétricos, elípticos, estreito-elípticos, largo-elípticos, oblongos ou ovados, 2,4-6,2 × 1,1-3,7 cm; ápice agudo, acuminado ou obtuso, mucronado, base obtusa ou subcordada. Racemos 4,6-19,6 cm compr., densifloros, 18-47 flores por racemo, pedúnculos alvo-tomentosos, glândulas puntiformes amarelas esparsas. Pedicelos 0,7-1,3 mm compr., tomentosos; brácteas externamente hirsutas, glândulas puntiformes amarelas presentes, 0,9-32,7 mm; cálice externamente seríceo, hirsuto, glândulas puntiformes amarelas abundantes, internamente glabrescente a esparso-seríceo, 4,6-7,7 mm compr., lacínio carenal 3,3-6,3 mm compr., os demais 2,8-6,1 mm compr.; corola 5,4-8,2 mm compr.; estandarte obovado, externamente pubérulo no ápice, glândulas puntiformes amarelas abundantes na região súperomediana, calosidade acima das aurículas, aurículas estreitas, ápice retuso, obtuso, 5,5-7,6 × 2,8-4,6 mm, unguícula 0,6-1 mm compr.; asas oblongas, estreito-oblongas, externamente pubérulas, glândulas puntiformes amarelas abundantes na região apical ou ao longo das pétalas, esculturas na região ínfero-mediana e basal, uniauriculadas, ápice obtuso, base obliquamente hastada, 4,5-7,6 × 1-1,7 mm, unguícula 0,8-1,4 mm compr.; pétalas da quilha falciformes, glabras ou externamente pubérulas, glândulas puntiformes amarelas esparsas, levemente cuculadas na região basal ou mediano-basal, ápice rostrado, base obliquamente hastada, 4,2-7,5 × 1,2-2,4 mm, unguícula 0,7-1,6 mm compr.; estames 3,5-7,1 mm compr., anteras oblongo-ovadas, 0,3-0,5 mm compr.; ovário oblongo, elíptico, elíptico-assimétrico, seríceo, tomentoso, subséssil, glândulas puntiformes amarelas abundantes sob o indumento, estilete filiforme, esparso-seríceo na base, estigma 0,1-0,2 mm compr. Legume reto, oblongo, não constricto entre as sementes, base obtusa, ápice agudo, mucronado, marrom, tomentoso, glândulas puntiformes amarelas presentes, 1,2-1,6 $\times$ 0,5-0,6 cm; sementes suborbiculares, marrons, marmoreadas, 2,9-3,6 × 2,8-3,3 mm; hilo elíptico, 0,7-1,1 mm compr.; funículo inserido no centro do hilo.

Material examinado: BRASIL. Mato Grosso do Sul: Aquidauana, 16/VI/2002, fl. fr., Sartori et al. 929a (CGMS); 20/ XI/2002, fl. fr., Hatschbach et al. 73.925 (MBM); 19/II/1970, fr., Hatschbach 23.814 (MBM); Bela Vista, 22/II/2006, fl. fr., Pott \& Dutra 14017 (CGMS); 17/III/1985, fl. fr., Hatschbach \& Silva 49.188 (MBM); Bonito, 09/XI/2002, fl. fr., Pott et al. 10529 (CGMS); Caracol, 24/X/1987, fl., Hatschbach 51.638 (MBM); Corumbá, 01/X/1976, fl. fr., Allem 16 (RB); 04/XI/1987, fl. fr., Pott et al. 3396 (CGMS); 08/IX/2006, fl. fr., Pott \& Pott 14172 (CGMS); Guia Lopes da Laguna, 23/II/2006, fl. fr., Pott \& Dutra 14045 (CGMS); Maracaju, 08/X/2003, fl., Hatschbach et al. 76.027 (MBM); Miranda, XII/1941, fr., Santos s.n. (R66891).

Rhynchosia balansae var. balansae caracteriza-se principalmente pelo hábito subarbustivo ereto, pelas estípulas caducas, pelos racemos longos (4,6-19,6 cm compr.) com 18 a 47 flores, estandarte e asas pubérulos e denso-glandulosos no ápice da face externa. Pode ser confundida com $R$. balansae var. psilantha Fortunato pela forma dos folíolos e pelo hábito volúvel nas porções apicais de alguns indivíduos. Esta variedade, no entanto, diferencia-se por apresentar peças da corola glabras ou com indumento pubérulo, racemos mais curtos (2,0-5,9 cm compr.) com 4-14 flores, além do hábito prostrado.

Segundo Fortunato (1983), Rhynchosia balansae apresenta o hábito muito variável, desde plantas apenas eretas a eretas com ápices volúveis ou ainda prostradas com ápices volúveis. Tais características permitiram a sinonimização de $R$. hagenbeckii Harms a $R$. balansae Micheli, que eram separadas quase que exclusivamente pelo hábito (Fortunato 1983, Grear 1978). Outro caráter muito 

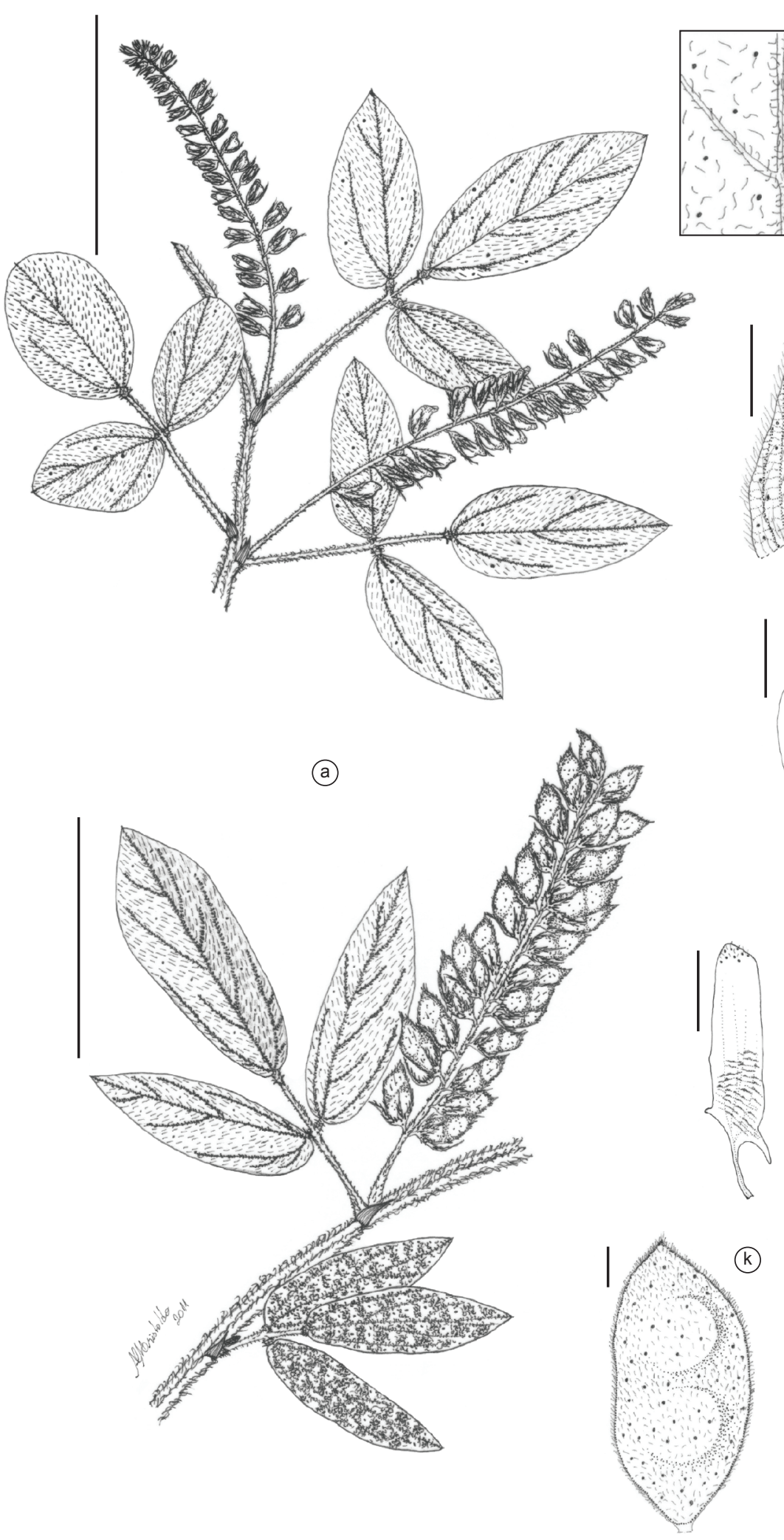

(e)
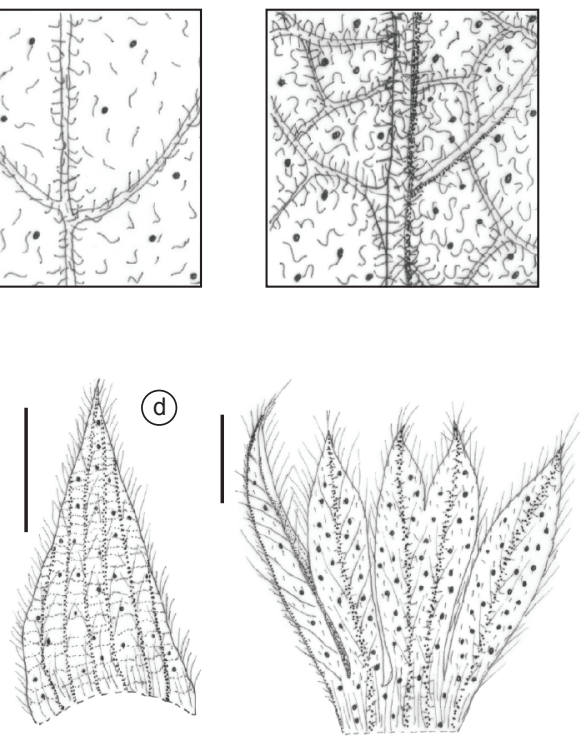

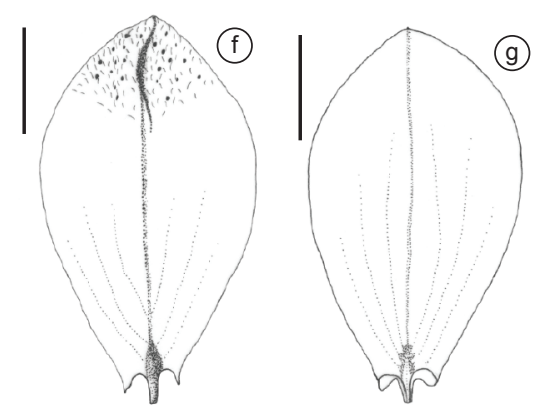

(h)

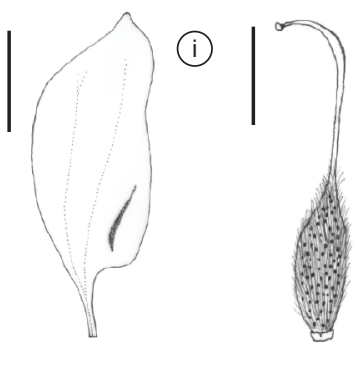

(1)

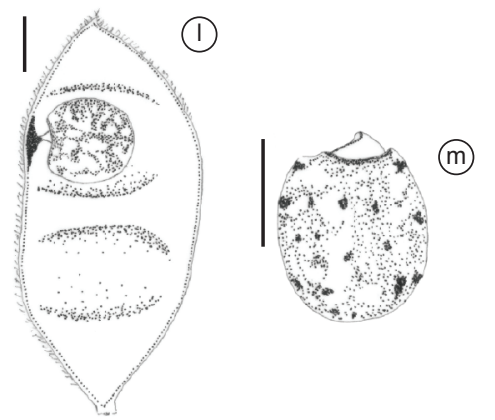

Figura 1. Rhynchosia balansae Micheli var. balansae: a) ramo com flores e frutos; b) detalhe do indumento da face adaxial do folíolo; c) detalhe do indumento da face abaxial do folíolo; d) estípula; e) cálice; f) face externa do estandarte; g) face interna do estandarte; h) asa; i) pétala da quilha; j) gineceu; k) fruto; 1) fruto aberto; m) semente (A. Pott 10529; Pott 14017; Pott 3396; Pott 1390). As escalas foram de $5 \mathrm{~cm}$ compr. para os ramos com flores e frutos, $1 \mathrm{~cm}$ compr. para detalhe do folíolo e $2 \mathrm{~mm}$ para as estruturas florais, fruto e estípula.

Figure 1. Rhynchosia balansae Micheli var. balansae: a) branches with flowers and fruits; b) detail of the indumentum of adaxial leaflet surface; c) detail of the indumentum of abaxial leaflet surface; d) stipule; e) calyx; f) external face of the standard; g) internal face of the standard; h) wing; i) keel petal; j) gynoecium; k) fruit; 1) open fruit; m) seed (A. Pott 10529; Pott 14017; Pott 3396; Pott 1390). The scales were $5 \mathrm{~cm}$ length for branches with flowers and fruit, $1 \mathrm{~cm}$ length for detail of leaflets and $2 \mathrm{~mm}$ for floral structure, fruit and stipule. 
variável, e que foi observado nas duplicatas da exsicata Pott \& Dutra 14017 (CGMS), é a forma do folíolo, que pode ser arredondado em indivíduos jovens até oblongo ou ovado nos adultos (Grear 1978). Características menos plásticas, no entanto, como o comprimento do racemo, quantidade de flores por racemo e presença ou ausência de indumento nas peças florais, aliadas às características vegetativas, permitiram o reconhecimento de duas variedades para a espécie conforme Fortunato (1983).

Distribuição geográfica e ambiente-Argentina, Paraguai e Brasil: MS, MT (Grear 1978, Fortunato 1983, 2012). Em Mato Grosso do Sul, ocorre no Pantanal, nas sub-regiões do Aquidauana, Paraguai e Miranda, em savana parque (campo cerrado sub-úmido), pastagem com regeneração de cerrado, vegetação secundária inicial em antiga pastagem cultivada, vegetação secundária de savana florestada (cerradão mesofítico), em solos arenosos ou argilosos sobre rocha de calcário dolomítico.

Floresce nos meses de fevereiro, março, junho, setembro a novembro; frutifica em fevereiro, março, junho, setembro a dezembro.

\section{Rhynchosia balansae var. psilantha Fortunato, Parodiana 2: 56.1983 (Figura 2)}

Ervas prostradas; ramos alvacentos, tomentosos, vilosos principalmente nos canalículos dos ramos apicais, pubérulos na base, tricomas glandulares de base bulbosa ausentes, glândulas puntiformes amarelas esparsas. Estípulas persistentes, ovadas, base truncada, côncava, ápice agudo, externamente alvo-tomentosas, glândulas puntiformes amarelas esparsas, internamente glabras, 3,74,2 $\times 1,9-1,7 \mathrm{~mm}$; um par de estipelas filiformes na base do folíolo apical, 1-1,2 mm compr., um par setiforme nos folíolos laterais, 0,1-0,5 mm compr., alvo-tomentosas. Pecíolos 1,3-2,3 cm compr., ráquis foliar $0,4-0,7 \mathrm{~cm}$ compr., tomentosos, vilosos, glândulas puntiformes amarelas ausentes. Folíolos discolores, bulados ou bulados apenas nas bordas, face adaxial alvo-pubescente, esparsoserícea, face abaxial alvo-vilosa; glândulas puntiformes amarelas presentes em ambas as faces, abundantes na face abaxial; folíolos apicais ovados, rômbicos ou largo-elípticos, 1,7-3 × 1,4-2,3 cm; laterais assimétricos, ovados, 1,4-2,6 × 1,1-1,9 cm; ápice obtuso ou agudo, mucronado, base subcordada. Racemos ou panículas 2-5,9 cm compr., laxifloros, 4-14 flores por racemo, pedúnculos alvo-tomentosos, glândulas puntiformes amarelas esparsas. Pedicelos 0,6-1,4 mm compr., tomentosos; brácteas externamente tomentosas, glândulas puntiformes amarelas esparsas, 3-4 × 0,5-0,7 mm; cálice externamente seríceo-pubescente, hirsuto-pubescente, glândulas puntiformes amarelas presentes, internamente glabrescente, 7-8,3 mm compr., lacínio carenal 6-7,3 mm compr., os demais 5,4-6,8 mm compr.; corola 5-6 mm compr.; estandarte obovado, externamente pubérulo no ápice, glândulas puntiformes amarelas esparsas, sem calosidade evidente, aurículas amplas, ápice obtuso, 5-6,3 × 2,6-3,6 mm, unguícula 0,9-1,1 mm compr.; asas oblongas, estreito-oblongas, glabras, glândulas puntiformes amarelas ausentes, esculturas na região ínfero-mediana, uniauriculadas, ápice obtuso, base obliquamente hastada, 5,2-5,9 × 1-1,1 mm, unguícula 1-1,3 mm compr.; pétalas da quilha falciformes, glabras, glândulas puntiformes amarelas ausentes, não cuculadas ou levemente na região basal, ápice rostrado, base obliquamente hastada, 5,2-6,3 × 1,5-1,7 mm, unguícula 1,1-1,3 mm compr.; estames 5,7-5,9 mm compr., anteras oblongo-elípticas, 0,3-0,4 mm compr.; ovário oblongo, elíptico, seríceo, subséssil, glândulas puntiformes amarelas abundantes sob o indumento, estilete filiforme, esparso-seríceo na base, estigma 0,1-0,2 mm compr. Legume reto, oblongo, não constricto entre as sementes, base obtusa, ápice agudo, mucronado, marrom, tomentoso, glândulas puntiformes amarelas presentes, 1,2-1,3 × 0,5-0,6 cm; sementes suborbiculares, marrom-avermelhadas, marmoreadas,
3,1-3,85 × 3,6-4,36 mm compr.; hilo elíptico, 0,7-1,6 mm compr.; funículo inserido no centro do hilo.

Material examinado: BRASIL. Mato Grosso do Sul: Aquidauana, 18/VIII/2003, fl. fr., Pott \& Pott 11336 (CGMS); Corumbá, 26/XI/1984, fl. fr., Pott 1390 (CGMS); 10/VIII/2008, fl., Pott 4322 (CGMS).

Rhynchosia balansae var. psilantha caracteriza-se principalmente pelo hábito prostrado, pelas estípulas persistentes, pelos racemos ou panículas geralmente curtos (2,0-5,9 cm compr.) com 4 a 14 flores, pelo estandarte com indumento esparso e não densamente glanduloso na face externa, além de asas e pétalas da quilha geralmente glabras. Pode ser confundida com $R$. balansae var. balansae pelo formato dos folíolos e o indumento tomentoso em toda a planta, mas se diferencia pelo hábito prostrado, pelas peças da corola pubérulas ou glabras, e pelo cálice esparso-glanduloso.

Distribuição geográfica e ambiente - Argentina, Paraguai (Fortunato 1983) e Brasil: MS. Ocorre apenas na borda oeste do estado de Mato Grosso do Sul, em área próxima da alta bacia da sub-região de Aquidauana e no Pantanal, sub-região do Paraguai, em cordilheira desmatada e campo inundável, sobre solos hidromórficos arenosos.

Floresce e frutifica nos meses de agosto a novembro.

\section{Rhynchosia clausseni Benth., Fl. Bras. 15(1B): 201. 1859 (Figura 3)}

Ervas eretas 10-30 cm alt.; ramos amarelados, hirsutos, tricomas glandulares de base bulbosa ausentes, glândulas puntiformes amarelas esparsas. Estípulas persistentes, estreito-elípticas, lanceoladas, base truncada, ápice agudo, externamente esparso-pubescentes, esparsohirsutas, glândulas puntiformes amarelas presentes, internamente glabrescentes, esparso-seríceas no ápice, 8-9 × 1,7-2,3 mm; um par de estipelas filiformes na base do folíolo apical, 1,2-2 mm compr., hirsutas. Pecíolos 3,3-6 cm compr., ráquis foliar 1,0-1,6 cm compr., hirsutos a esparso-hirsutos, glândulas puntiformes amarelas esparsas. Folíolos discolores, não bulados ou bulados apenas nas bordas, face adaxial esparso-serícea, face abaxial esparso-pubescente, esparsohirsuta; glândulas puntiformes amarelas presentes em ambas as faces, abundantes na face abaxial; folíolos apicais rômbicos, largo-elípticos, ovados, largo-ovados, 3,4-5,1 × 3,2-4,4 cm; laterais assimétricos, ovados, largo-ovados, largo-elípticos, 2,9-4,3 × 2,2-3,2 cm; ápice obtuso ou arredondado, mucronado, base subcordada, raro obtusa. Racemos corimbiformes 3,6-7,4 cm compr., 3-6 flores por racemo, pedúnculos amarelo-hirsutos, glândulas puntiformes amarelas presentes. Pedicelos 1,5-2,2 mm compr., hirsutos; brácteas externamente hirsutas, glândulas puntiformes amarelas esparsas, 2,6-4,8 × 1-1,4 mm; cálice externamente esparso-hirsuto, glândulas puntiformes amarelas presentes, internamente pubérulo, 14,4-16,1 mm compr., lacínio carenal 11,5-14 mm compr., os demais 12,6-13,9 mm compr.; corola 5,2-9,7 mm compr.; estandarte obovado, glabro em ambas as faces, glândulas puntiformes amarelas ausentes, calosidade acima das aurículas, aurículas estreitas, ápice obtuso, 4,7-8,5 × 3,4-5,3 mm, unguícula 1,63-2,9 mm compr.; asas oblongas, glabras, glândulas puntiformes amarelas ausentes, esculturas nas regiões mediana e basal, uniauriculadas, ápice obtuso, base obliquamente hastada, 4,96-8,2 × 1,16-2,6 mm, unguícula 1,9-2,4 mm compr.; pétalas da quilha falciformes, obovadas, glabras, glândulas puntiformes amarelas ausentes, cuculadas na região mediano-basal, ápice obtuso, levemente rostrado, base obliquamente hastada, 5-8,3 × 1,5-2,7 mm, unguícula 0,7-1,6, mm compr.; estames 3,6-19 mm compr., anteras oblongas, ovadas, 0,4-0,6 mm compr.; ovário ovado, seríceo, subséssil, glândulas puntiformes amarelas abundantes sob o indumento, estilete filiforme, glabro, estigma 0,3-0,4 $\mathrm{mm}$ compr. Legume reto, oblongo ou lanceolado, não constricto entre as sementes, base cuneada, ápice agudo, 


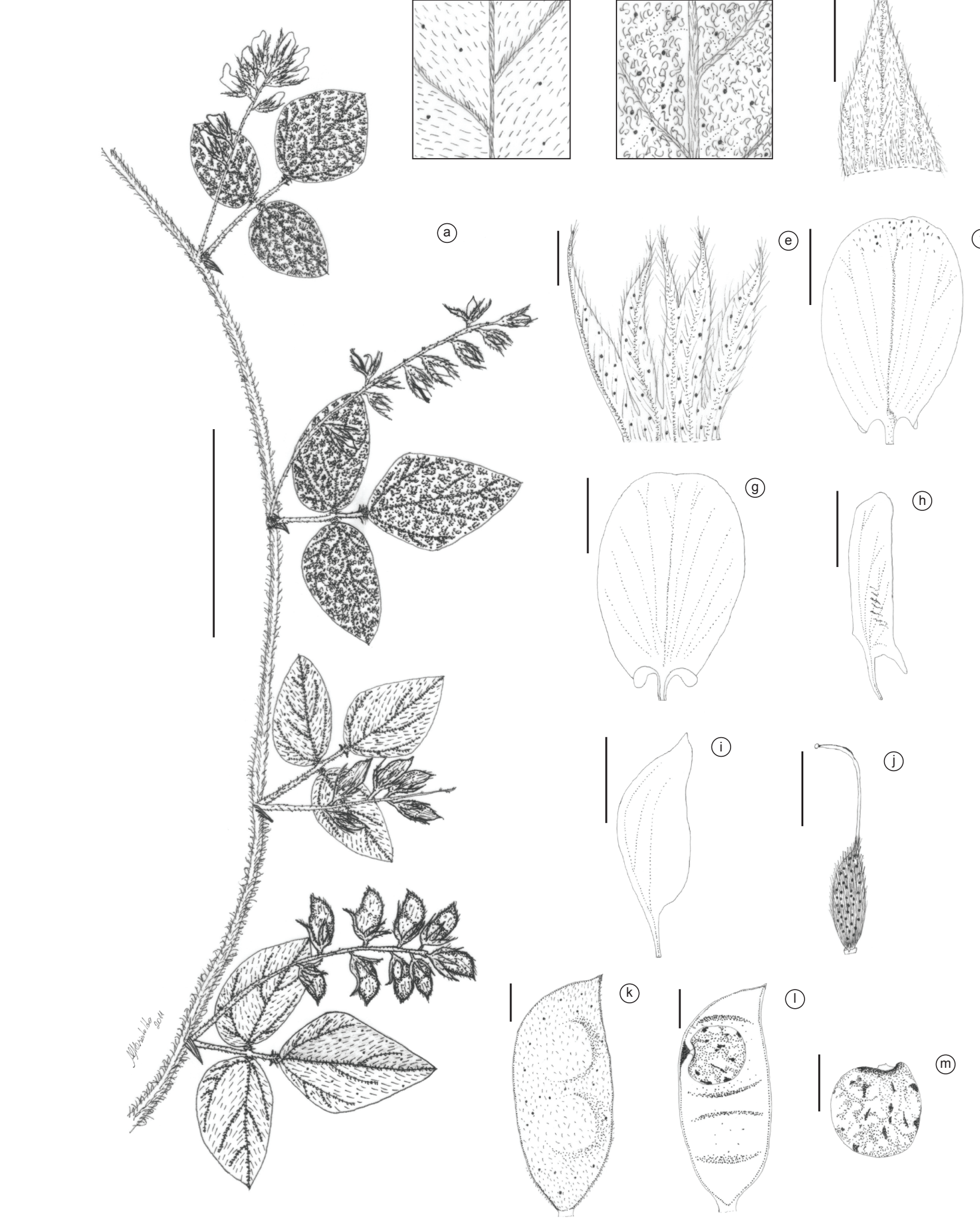

(b)

(c)

(d)
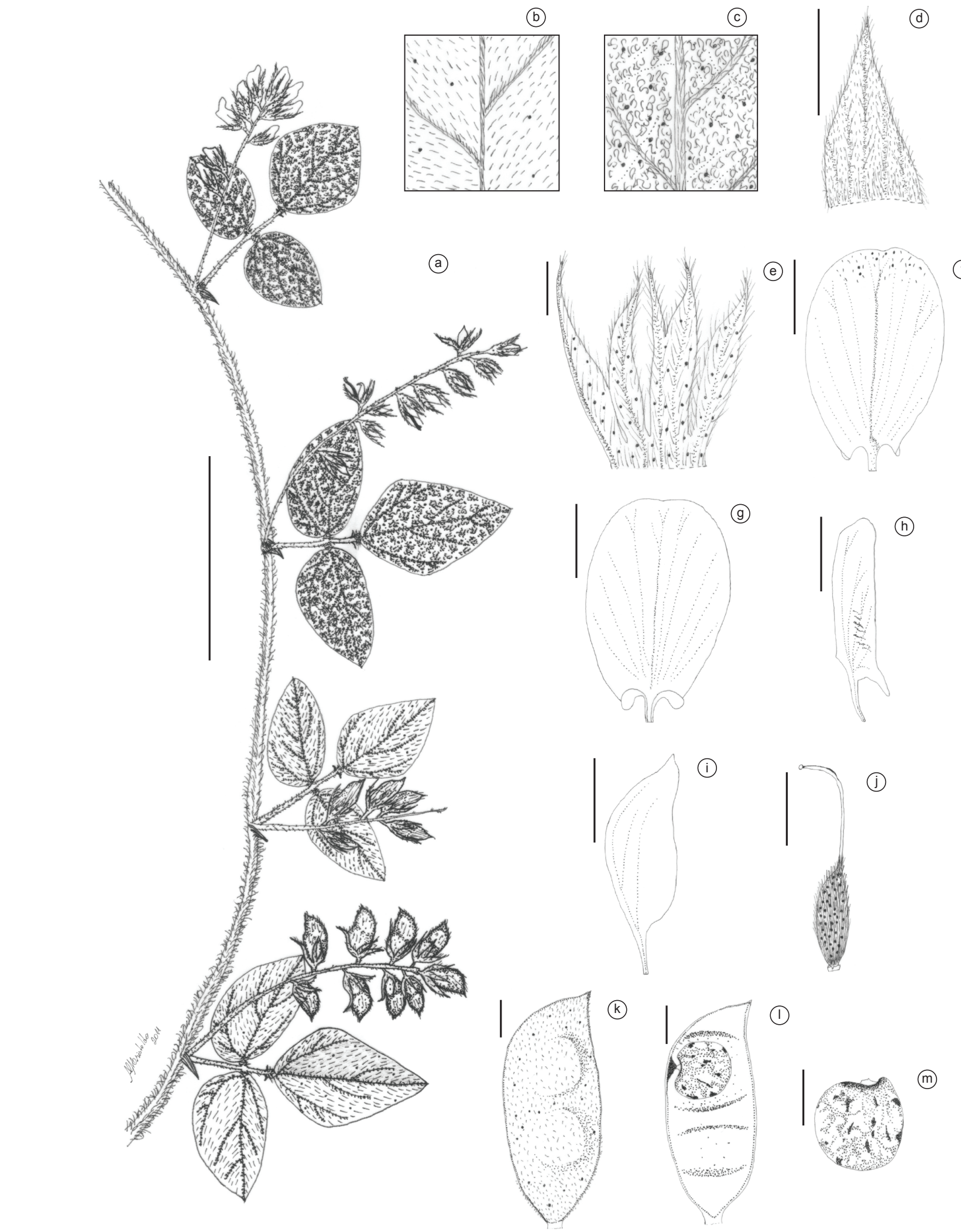

Figura 2. R. balansae var. psilantha Fortunato: a) ramo com flores e frutos; b) detalhe do indumento da face adaxial do folíolo; c) detalhe do indumento da face abaxial do folíolo; d) estípula; e) cálice; f) face externa do estandarte; g) face interna do estandarte; h) asa; i) pétala da quilha; j) gineceu; $\mathrm{k}$ ) fruto; 1) fruto aberto; m) semente (Pott 4322; Pott 1390). As escalas foram de $5 \mathrm{~cm}$ compr. para os ramos com flores e frutos, $1 \mathrm{~cm}$ compr. para detalhe do folíolo e $2 \mathrm{~mm}$ para as estruturas florais, fruto e estípula.

Figure 2. $R$. balansae var. psilantha Fortunato: a) branches with flowers and fruits; b) detail of the indumentum of adaxial leaflet surface; c) detail of the indumentum of abaxial leaflet surface; d) stipule; e) calyx; f) external face of the standard; g) internal face of the standard; h) wing; i) keel petal; j) gynoecium; k) fruit; 1) open fruit; $\mathrm{m}$ ) seed (Pott 4322; Pott 1390). The scales were $5 \mathrm{~cm}$ length for branches with flowers and fruit, $1 \mathrm{~cm}$ length for detail of leaflets and $2 \mathrm{~mm}$ for floral structure, fruit and stipule. 
(b)

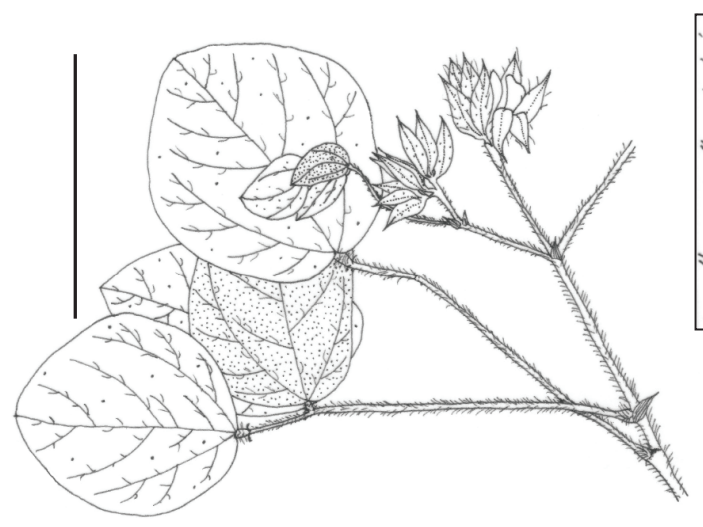

(a)

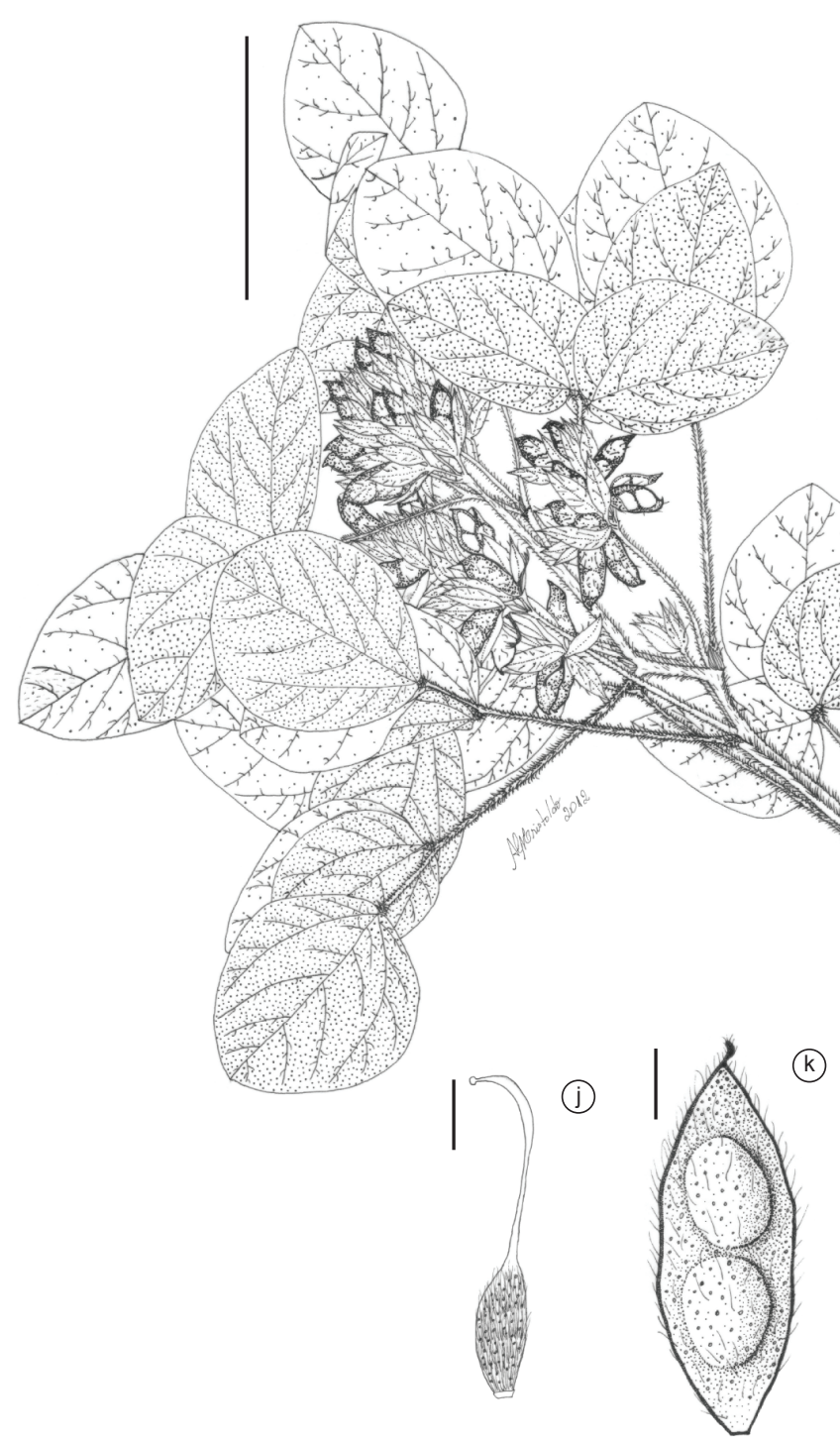

(c)

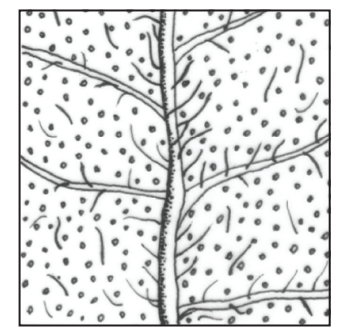

(d)

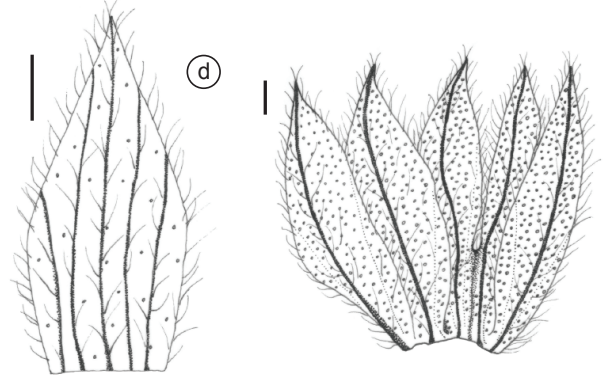

(e)

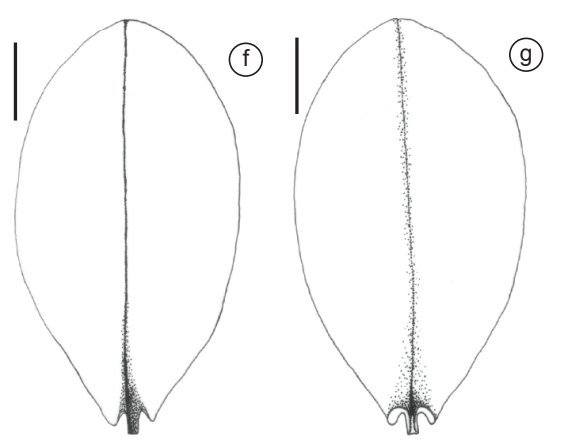

(1)

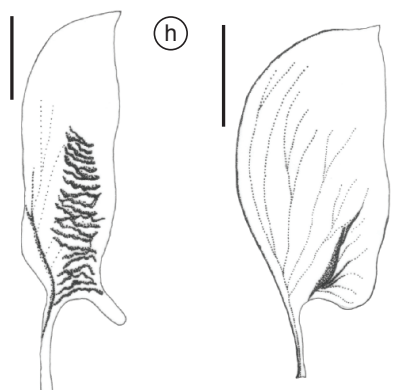

(i)
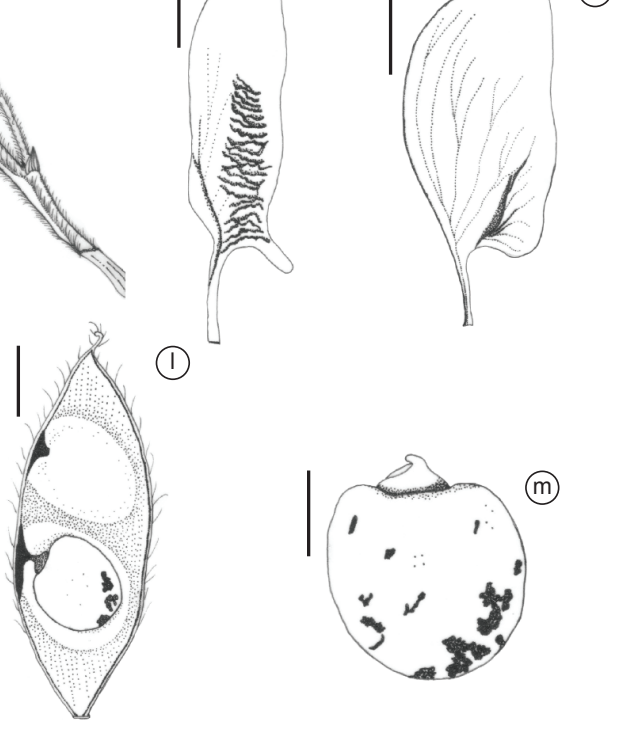

Figura 3. R. clausseni Benth.: a) ramo com flores e frutos; b) detalhe do indumento da face adaxial do folíolo; c) detalhe do indumento da face abaxial do folíolo; d) estípula; e) cálice; f) face externa do estandarte; g) face interna do estandarte; h) asa; i) pétala da quilha; j) gineceu; k) fruto; l) fruto aberto; $\mathrm{m}$ ) semente (Hatschbach 33932). As escalas foram de $5 \mathrm{~cm}$ compr. para os ramos com flores e frutos, $1 \mathrm{~cm}$ compr. para detalhe do folíolo e $2 \mathrm{~mm}$ para as estruturas florais, fruto e estípula.

Figure 3. R. clausseni Benth.: a) branches with flowers and fruits; b) detail of the indumentum of adaxial leaflet surface; c) detail of the indumentum of abaxial leaflet surface; d) stipule; e) calyx; f) external face of the standard; g) internal face of the standard; h) wing; i) keel petal; j) gynoecium; k) fruit; l) open fruit; $\mathrm{m}$ ) seed (Hatschbach 33932). The scales were $5 \mathrm{~cm}$ length for branches with flowers and fruit, $1 \mathrm{~cm}$ length for detail of leaflets and $2 \mathrm{~mm}$ for floral structure, fruit and stipule. 
mucronado, preto, marrom-escuro, hirsuto, glândulas puntiformes amarelas presentes, 1,7-1,9 $\times 0,6-0,7 \mathrm{~cm}$; sementes suborbiculares, largo-elípticas, marrons, marmoreadas, 3,4-3,5 × 2,8-3 mm compr.; hilo oblongo, 1-1,1 mm compr.; funículo inserido no centro do hilo.

Material examinado: BRASIL. Mato Grosso do Sul: Camapuã, 08/II/1974, fl. fr., Hatschbach 33923 (MBM); Campo Grande, 14/ VIII/1970, fr., Hatschbach \& Guimarães 24636 (MBM).

Material adicional: BRASIL. Mato Grosso: Cuiabá, 01/II/1986, fl. fr., Carvalho \& Lewis 2155 (UFMT).

Rhynchosia clausseni caracteriza-se pelo hábito ereto, pelos folíolos em sua maioria rômbicos, com face adaxial esparso-serícea e face abaxial esparso-pubescente ou esparso-hirsuta, glandulosos em ambas as faces, pelos pecíolos bem desenvolvidos, pelas estípulas persistentes e racemos corimbiformes. $R$. clausseni compartilha características como forma dos folíolos e tipo de inflorescência com $R$. corylifolia, mas o hábito, o indumento e a presença de glândulas puntiformes amarelas na face adaxial dos folíolos são características suficientes para a correta distinção.

Distribuição geográfica e ambiente - Paraguai e Brasil: MS, DF, GO, MG (Bentham 1859, Grear 1978, Fortunato 2012). R. clausseni foi registrada apenas no centro-norte do Estado em áreas de savana (cerrado).

Floresce e frutifica nos meses de fevereiro e agosto.

\section{Rhynchosia corylifolia Mart. ex Benth., Fl. Bras. 15(1B): 202. 1859 (Figura 4)}

Ervas ou subarbustos prostrados; ramos amarelados ou alvacentos, tomentosos, vilosos nos ramos apicais, glabrescentes a esparso-pubescentes na base, tricomas glandulares de base bulbosa ausentes, glândulas puntiformes amarelas esparsas. Estípulas persistentes, ovadas, largo-ovadas, cordadas, base truncada, ápice agudo ou obtuso, externamente alvo-pubescentes, vilosas, esparsotomentosas, glândulas puntiformes amarelas esparsas, internamente glabrescentes a esparso-vilosas, 4,3-11,6 × 1,6-9,8 mm; um par de estipelas setiformes na base do folíolo apical, 0,3-0,7 mm compr., vilosas. Pecíolos 0,2-1,6 cm compr., ráquis foliar 0,3-1,3 cm compr., alvo-hirsutos, glândulas puntiformes amarelas esparsas. Folíolos discolores, bulados, face adaxial glabrescente, esparso-pubescente, serícea, tricomas glandulares de base bulbosa esparsos; face abaxial alvo-tomentosa, esparso-tomentosa, glândulas puntiformes amarelas presentes; folíolos apicais oblatos, orbiculares, rômbicos, orbicularromboidais, elípticos, largo-elípticos, largo-ovados, obovados, largoobovados, 2-9 × 1,6-6 cm; laterais assimétricos, oblatos, orbiculares, ovados, largo-ovados, elípticos, largo-elípticos, 1,2-6 × 1,1-4 cm; folíolos das folhas unifolioladas oblatos ou triangulares, 4-4,5 $\times$ 3,4-5,1 cm; ápice agudo, obtuso, retuso ou emarginado, mucronado, base obtusa, cordada ou subcordada, arredondada ou truncada. Racemos corimbiformes 4,8-14,2 cm compr., 7-12 flores por racemo, pedúnculos alvo-vilosos, tomentosos, tricomas glandulares de base bulbosa e glândulas puntiformes amarelas esparsas. Pedicelos 1,7-6,1 mm compr., vilosos, tomentosos; brácteas externamente pubescentes, vilosas, glândulas puntiformes amarelas esparsas, 2,3-7 × 1-4,5 mm; cálice externamente pubescente, seríceo, glândulas puntiformes amarelas abundantes, tricomas glandulares de base bulbosa esparsos, internamente esparso-seríceo, 7-18,2 mm compr., lacínio carenal 5,6-15,2 mm compr., os demais 3,8-14,4 mm compr.; corola 6-8,1 mm compr.; estandarte obovado a largo-obovado, oblongo ou suborbicular, glabro ou externamente esparso-seríceo no ápice, raro estrias avermelhadas ou vináceas, glândulas puntiformes amarelas ausentes, calosidade acima das aurículas, aurículas estreitas, ápice retuso ou emarginado, 5,6-10,4 × 3,5-6,2 mm, unguícula 0,8-1,8 mm compr.; asas oblongas, glabras, glândulas puntiformes amarelas ausentes, esculturas na região ínfero-mediana, raro estrias avermelhadas, uniauriculadas, ápice obtuso, base obliquamente hastada, 5,2-10,4 × 1,3-2 mm, unguícula 0,9-1,9 mm compr.; pétalas da quilha falciformes, glabras, glândulas puntiformes amarelas ausentes, cuculadas na região mediano-basal, ápice obtuso, levemente rostrado, base obliquamente hastada, 5,8-10,3 × 2-3,6 mm, unguícula 1,4-2 mm compr.; estames 4,2-11 mm compr., anteras oblongas, elípticas, 0,3-0,9 mm compr.; ovário ovado, seríceo, subséssil, glândulas puntiformes amarelas presentes sob o indumento, estilete filiforme, glabro, estigma 0,1-0,3 mm compr. Legume oblongo ou ovado-oblongo, não constricto entre as sementes, base e ápice obtusos, ápice mucronado, marrom, marrom-escuro, esparso-pubescente, hirsuto, tomentoso, glândulas puntiformes amarelas e tricomas glandulares de base bulbosa presentes, 1,5-2 × 0,6-0,9 cm; sementes suborbiculares, marrons, marmoreadas, 2,9-3,7 × 2,7-3,8 mm; hilo oblongo, 1,2-1,3 mm compr.; funículo inserido no centro do hilo.

Material examinado: BRASIL. Mato Grosso do Sul: Bandeirantes, III/2001, fl. fr., Pirani 4825 (HUEFS); Bonito, 08/ XI/2002, fr., Pott 10523 (CGMS); 08/XI/2002, fl. fr., Pott 10521 (CGMS); Caarapó, 23/V/1978, fr., Allem \& Vieira 1986 (HUEFS); Campo Grande, III/1955, fr., Neves s.n. (RBR11168); 31/VII/1999, fr., Motta s.n. (CGMS 10069); VIII/2002, fl. fr., Pott 9868 (CGMS); 03/VIII/2007, fr., Assunção et al. 25 (CGMS); 28/VIII/2007, fl., Cristaldo 182 (CGMS); 04/IX/2007, fl. fr., Cristaldo \& Alves 183 (CGMS); 19/IX/1990, fr., Resende 232 (CGMS); 19/X/2007, fr., Cristaldo 191 (CGMS); Dourados, 24/I/1979, fl. fr., Saturnino 455 (PAMG); I/1979, fl. fr., Saturnino 440 (PAMG); 16/V/1976, fl., Hatschbach 38.690 (MBM); Ponta Porá, 15/V/1976, fl., Hatschbach 38.668 (MBM); Porto Murtinho, 10/IX/2005, Pott \& Pott 13406 (CGMS); 9/XII/2005, fl. fr., Pott 13766 (CGMS); Rio Brilhante, X/2004, fl. fr., Pott 11923 (CGMS); 16/II/1970, fl. fr., Hatschbach 23.685 (MBM); 26/X/1970, fl., Hatschbach 25.255 (MBM); Selvíria, 30/VII/1991, fr., Tiritan 72 (HRCB, RB); 27/VIII/1991, fr., Tiritan \& Paiva 725 (RB).

Rhynchosia corylifolia caracteriza-se pelo hábito prostrado, pelos folíolos bulados, racemos corimbiformes e pelas estípulas ovadas, largo-ovadas ou cordadas, persistentes. Alguns indivíduos podem ser confundidos com $R$. leucophylla devido ao formato de seus folíolos e ao indumento geralmente alvo-tomentoso na face abaxial dos folíolos, mas o hábito prostrado, os pecíolos e ráquis foliar desenvolvidos (0,2-1,6 cm compr.) em $R$. corylifolia são características suficientes para a correta distinção.

Distribuição geográfica e ambiente - Argentina, Bolívia, Paraguai, Uruguai e Brasil: MS, PR, RS, SC, SP (Bentham 1859, Grear 1978, Fortunato 1983, 2012, Miotto 1988). R. corylifolia é encontrada em todas as regiões do Estado, exceto na região norte, em solos argilosos ou com afloramento de rocha calcária ou basáltica. Ocorre em savana (cerrado), savana parque (campo cerrado) e áreas antropizadas (rebrota de vegetação de cerrado, pós-fogo).

Floresce nos meses de janeiro a maio, e de agosto a dezembro; frutifica nos meses de janeiro a março, em maio e de julho a dezembro.

\section{Rhynchosia edulis Griseb., Abh. Königl. Ges. Wiss. Göttingen 19: 123. 1874 (Figura 5)}

Trepadeiras; ramos amarelados ou alvacentos, pubescentes, esparso-tomentosos, tricomas glandulares de base bulbosa e glândulas puntiformes castanhas ou pretas esparsas. Estípulas persistentes, lanceoladas, estreito-triangulares, base truncada, ápice acuminado, externamente alvo-pubescentes, tricomas glandulares de base bulbosa e glândulas puntiformes castanhas presentes, internamente seríceas, 2,5-4,9 $\times 0,5-0,8 \mathrm{~mm}$; um par de estipelas filiformes na base do folíolo apical e um par nos folíolos laterais, 0,6-1,5 mm compr., tomentosas. Pecíolos 0,9-3,8 cm compr., ráquis foliar 0,5-1,9 cm compr., pubescentes, esparso-tomentosos, tricomas glandulares 


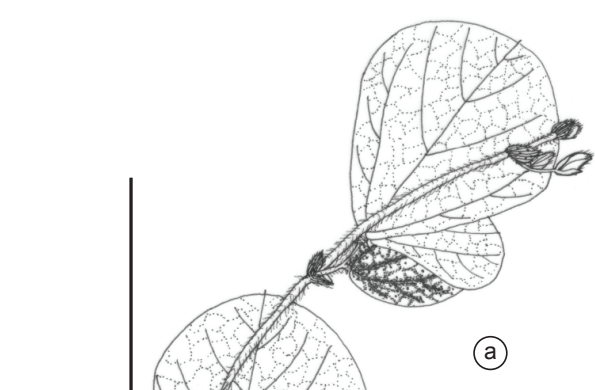

(b)

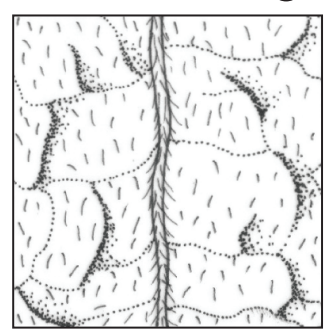

(c)
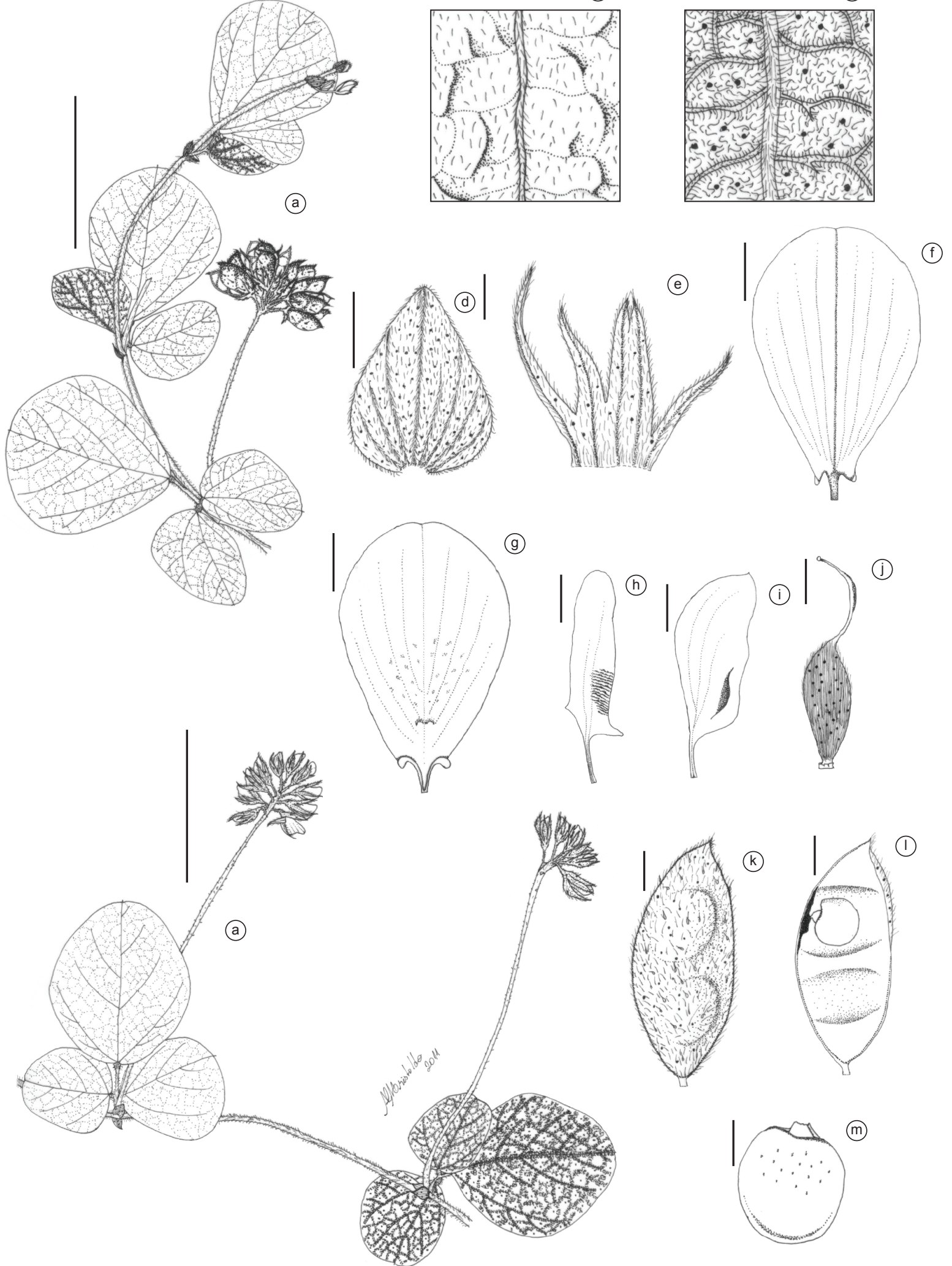

(b)
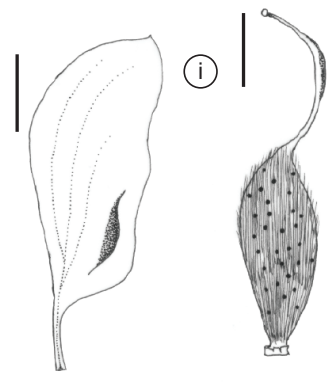

(i)
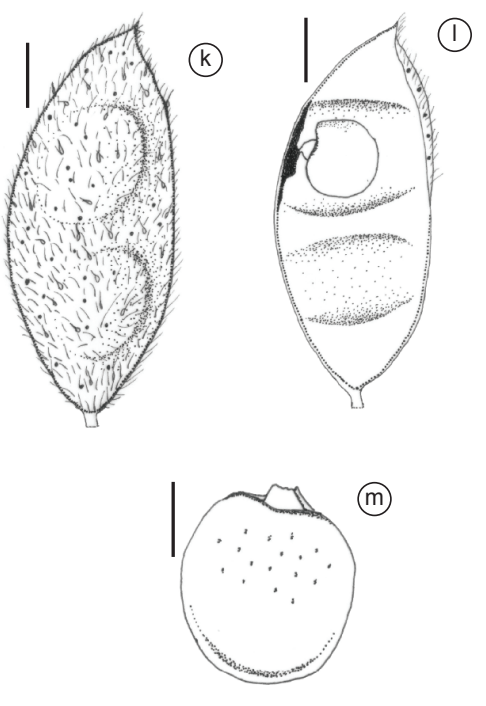

Figura 4. Rhynchosia corylifolia Mart. ex Benth.: a) ramo com flores e frutos; b) detalhe do indumento da face adaxial do folíolo; c) detalhe do indumento da face abaxial do folíolo; d) estípula; e) cálice; f) face externa do estandarte; g) face interna do estandarte; h) asa; i) pétala da quilha; j) gineceu; k) fruto; 1) fruto aberto; m) semente (Pott 11923; Pott 9868; Pott 10521). As escalas foram de $5 \mathrm{~cm}$ compr. para os ramos com flores e frutos, $1 \mathrm{~cm}$ compr. para detalhe do folíolo e $2 \mathrm{~mm}$ para as estruturas florais, fruto e estípula.

Figure 4. Rhynchosia corylifolia Mart. ex Benth.: a) branches with flowers and fruits; b) detail of the indumentum of adaxial leaflet surface; c) detail of the indumentum of abaxial leaflet surface; d) stipule; e) calyx; f) external face of the standard; g) internal face of the standard; h) wing; i) keel petal; j) gynoecium; k) fruit; 1) open fruit; m) seed (Pott 11923; Pott 9868; Pott 10521). The scales were $5 \mathrm{~cm}$ length for branches with flowers and fruit, $1 \mathrm{~cm}$ length for detail of leaflets and $2 \mathrm{~mm}$ for floral structure, fruit and stipule. 

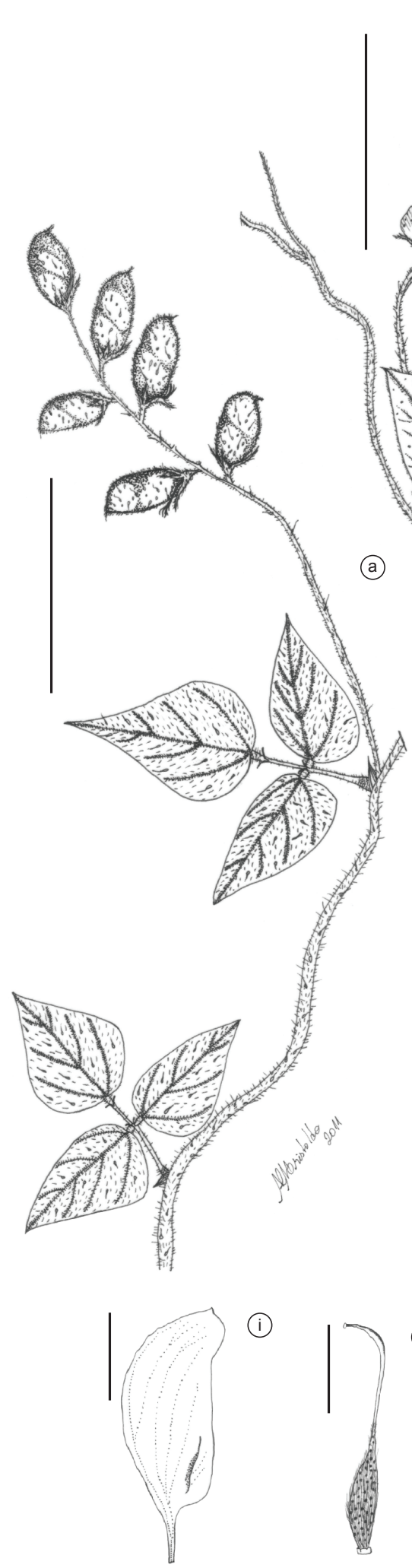

(i)
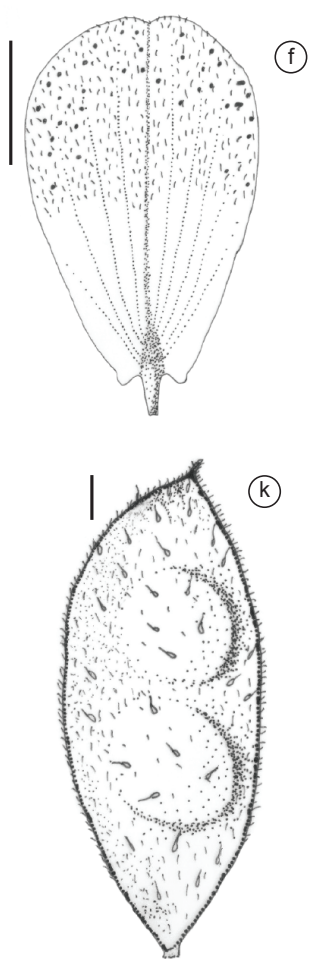

$(\uparrow$ (b)

(c)

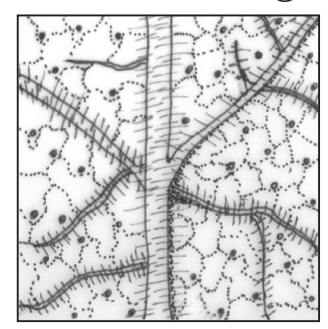

(d)

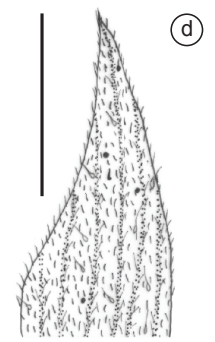

(e)
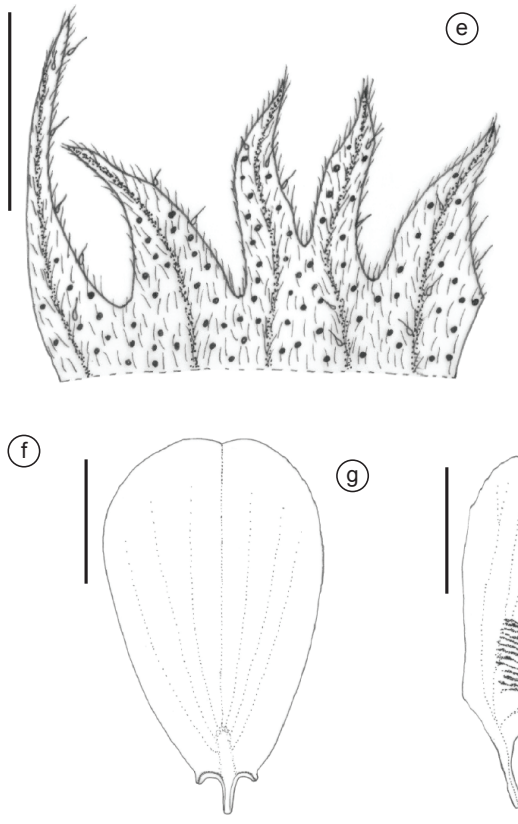

(9)
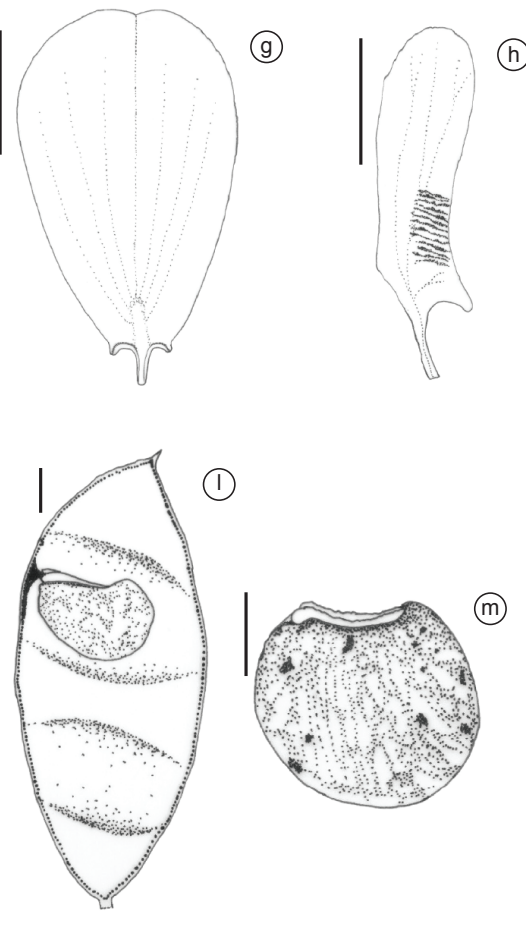

Figura 5. R. edulis Griseb.: a) ramo com flores e frutos; b) detalhe do indumento da face adaxial do folíolo; c) detalhe do indumento da face abaxial do folíolo; d) estípula; e) cálice; f) face externa do estandarte; g) face interna do estandarte; h) asa; i) pétala da quilha; j) gineceu; k) fruto; l) fruto aberto; m) semente (Pott 8867; Pott 14281). As escalas foram de $5 \mathrm{~cm}$ compr. para os ramos com flores e frutos, $1 \mathrm{~cm}$ compr. para detalhe do folíolo e $2 \mathrm{~mm}$ para as estruturas florais, fruto e estípula.

Figure 5. R. edulis Griseb.: a) branches with flowers and fruits; b) detail of the indumentum of adaxial leaflet surface; c) detail of the indumentum of abaxial leaflet surface; d) stipule; e) calyx; f) external face of the standard; g) internal face of the standard; h) wing; i) keel petal; j) gynoecium; k) fruit; 1) open fruit; m) seed (Pott 8867; Pott 14281). The scales were $5 \mathrm{~cm}$ length for branches with flowers and fruit, $1 \mathrm{~cm}$ length for detail of leaflets and $2 \mathrm{~mm}$ for floral structure, fruit and stipule. 
de base bulbosa presentes. Folíolos discolores, não bulados, face adaxial alvo-pubescente, esparso-tomentosa, tricomas glandulares de base bulbosa esparsos, face abaxial esparso-tomentosa, glândulas puntiformes castanhas, esverdeadas ou pretas presentes; folíolos apicais rômbicos, trulados, 2,2-5,1 × 1,5-4,2 cm; laterais assimétricos, rômbicos, trulados, 1,4-5,4 × 1,2-3,5 cm; ápice agudo ou acuminado, mucronado, base cuneada. Racemos 6,3-11,8 cm compr., laxifloros, 7-21 flores por racemo, pedúnculos alvacentos, esparso-tomentosos, tricomas glandulares de base bulbosa presentes. Pedicelos 1,7-3,0 mm compr., esparso-tomentosos, tricomas glandulares de base bulbosa presentes; brácteas externamente tomentosas, tricomas glandulares de base bulbosa presentes, 1,7-2,0 $\times 0,5-0,9 \mathrm{~mm}$; cálice externamente pubescente, tricomas glandulares de base bulbosa e glândulas puntiformes amarelas, esverdeadas ou pretas presentes, internamente esparso-seríceo, 4,0-6,0 mm compr., lacínio carenal 2,8-4,3 mm compr., os demais 1,7-2,6 mm compr.; corola 7,1-7,5 mm compr.; estandarte obovado, oblongo-obovado, externamente pubescente, tricomas glandulares de base bulbosa e glândulas puntiformes amarelas, esverdeadas presentes, sem calosidade evidente, aurículas estreitas, ápice retuso ou truncado, 7,0-7,4 × 3,9-4,5 mm, unguícula 1,0-1,2 mm compr.; asas estreito-oblongas, glabras ou externamente pubérulas no ápice, glândulas puntiformes amarelas ausentes, esculturas na região ínfero-mediana, uniauriculadas, ápice obtuso, base obliquamente hastada, 5,7-6,4 × 1,2-1,4 mm, unguícula 1,3-1,7 mm compr.; pétalas da quilha falciformes, glabras, glândulas puntiformes amarelas ausentes, levemente cuculadas na região mediano-basal, ápice obtuso, levemente rostrado, base obliquamente hastada, 6,0-7,0 × 1,8-2,5 mm, unguícula 1,8-1,9 mm compr.; estames 5,3-6,8 mm compr., anteras oblongas, 0,3-0,5 mm compr.; ovário oblongo, elíptico assimétrico, seríceo, subséssil, glândulas puntiformes esverdeadas presentes sob o indumento, estilete filiforme, esparso-seríceo na base, estigma 0,2-0,3 $\mathrm{mm}$ compr. Legume reto, oblongo-elíptico, não constricto entre as sementes, base cuneada, ápice obtuso, mucronado, marrom, esparso-pubescente, tricomas glandulares de base bulbosa e glândulas puntiformes castanhas ou pretas presentes, 1,9-2,2 $\times 0,6-0,7 \mathrm{~cm}$; sementes suborbiculares, marrons, marmoreadas, 3,9-4,1 × 4,3-4,4 mm compr.; hilo oblongolinear, 1,9-2,3 mm compr.; funículo inserido no ápice do hilo.

Material examinado: BRASIL. Mato Grosso do Sul: Bela Vista, 17/III/1985, fl. fr., Hatschbach \& Silva 49.191 (MBM); Campo Grande, 25/I/1979, fl., Heringer 788 (RB, IBGE); 11/VI/1985, fr., Oliveira s.n. (CGMS 01671); Corumbá, 01/X/1976, fl., Allem 10 (RB); 31/X/1984, fl. fr., Pott 1692 (CGMS); 10/IV/1985, fl. fr., Pott 149 (CGMS); 05/VIII/1987, fl. fr., Pott et al. 3220 (CGMS); 11/ IV/1992, fr., Resende et al. 688 (CGMS); Jateí, 12/XII/2006, fl. fr., Pott 14281 (CGMS); Maracaju, 29/XII/1973, fl. fr., Sucre 10489 (RB); Porto Murtinho, 15/IV/2005, fl., Nunes et al. $201 B$ (CGMS); Terenos, 01/IV/2006, fl. fr., Pott et al. 8867 (CGMS).

Rhynchosia edulis caracteriza-se pelo hábito volúvel, pelos folíolos rômbicos, legumes oblongo-elípticos e, sobretudo, pelas glândulas punctiformes, que se apresentam esverdeadas ou escurecidas em material herborizado, e pela inserção do funículo na porção apical do hilo, ao invés de ser central como nas outras Rhynchosia. Geralmente é confundida com R. minima pelo hábito e pela presença de glândulas puntiformes comumente castanhas nos folíolos, mas se diferencia por características como a presença de tricomas glandulares de base bulbosa em toda a planta, frutos retos, estípulas persistentes, além do funículo inserido na porção apical do hilo.

Segundo Fortunato (2000), a forma dos frutos e a presença de tricomas glandulares de base bulbosa são justamente algumas das características que separam Rhynchosia edulis e R. minima em dois grupos da seção Copisma, grupo $\alpha$ e $\beta$, respectivamente. No material analisado, observaram-se estrias avermelhadas ou vináceas na face externa do estandarte e, por vezes, nas asas e pétalas da quilha, características que auxiliam na distinção entre $R$. edulis e $R$. minima. Observou-se também que as aurículas do estandarte são tão estreitas que quase não se percebe que são infletidas.

Distribuição geográfica e ambiente - desde o sul dos Estados Unidos até a Argentina, e Brasil: BA, CE, GO, MG, PR, RS, SP, SC (Grear 1978, Miotto 1988, Fortunato 1983, 2012), MS. Rhynchosia edulis é encontrada no centro, sul e oeste do Estado e no Pantanal, nas sub-regiões do Paraguai e Nabileque. Ocorre na borda de floresta ripária (mata ciliar), savana estépica arborizada (Chaco) e áreas antropizadas (barranco de córrego), em solos argilosos.

Floresce nos meses de janeiro, março, abril, agosto, outubro e dezembro; frutifica janeiro, março, abril, junho, agosto, outubro e dezembro.

\section{Rhynchosia leucophylla Benth., Fl. Bras. 15(1B): 202. 1859 (Figura 6)}

Ervas ou subarbustos eretos, 40-80 cm alt; ramos alvacentos, hirsutos, seríceos, denso-seríceos nos ramos apicais, glabros ou seríceos na base, tricomas glandulares de base bulbosa ausentes, glândulas puntiformes amarelas esparsas. Estípulas caducas, ovadas ou triangulares, base truncada, ápice agudo, externamente alvoseríceas, glândulas puntiformes amarelas ausentes, internamente glabras, 4-6,1 × 2-2,9 mm; estipelas ausentes. Pecíolos subsésseis, 0,8-1,5 mm compr., ráquis foliar ausente, apenas pulvínulo, hirsutos, seríceos, denso-seríceos, glândulas puntiformes amarelas ausentes. Folíolos discolores, não bulados ou bulados apenas nas bordas, face adaxial argênteo-serícea, face abaxial argênteo-velutina, tomentosa, denso-serícea, glândulas puntiformes geralmente não evidentes; folíolos apicais elípticos, largo-elípticos, suborbiculares, trulados, obovados, 3,2-7,4 × 1,8-5 cm; laterais assimétricos, elípticos, ovados, 2,1-5,5 × 0,9-2,8 cm; ápice agudo, obtuso, raro emarginado, mucronado, base aguda, cuneada. Racemos corimbiformes $3,4-7,8 \mathrm{~cm}$ compr., 10-26 flores por racemo, pedúnculos alvo-seríceos, densoseríceos, flores no ápice do pedúnculo, glândulas puntiformes amarelas ausentes. Pedicelos 2,3-3,6 mm compr., seríceos, densoseríceos; brácteas externamente seríceas, glândulas puntiformes amarelas presentes, 3,9-6,3 × 0,5-1,2 mm; cálice externamente seríceo, tricomas glandulares de base bulbosa e glândulas puntiformes amarelas presentes, internamente esparso-seríceo, 11-11,9 mm compr., lacínio carenal 9,4-10,2 mm compr., os demais 7,9-8,5 mm compr.; corola 8,7-11,4 mm compr.; estandarte obovado, estreitoobovado, glabro em ambas as faces, glândulas puntiformes amarelas ausentes, sem calosidade evidente, aurículas estreitas, ápice emarginado, retuso, 8,3-10,3 × 4-4,4 mm, unguícula 1-1,8 mm compr.; asas estreito-oblongas, glabras, glândulas puntiformes amarelas ausentes, esculturas na região ínfero-mediana, uniauriculadas, ápice obtuso, base obliquamente hastada, 8,3-10 × 1,4-3,8 mm, unguícula 1,2-2,6 mm compr.; pétalas da quilha falciformes, glabras, glândulas puntiformes amarelas ausentes, cuculadas na região mediano-basal, ápice rostrado, base obliquamente hastada, 8,1-9,5 × 2-2,5 mm, unguícula 2,6-2,7 mm compr.; estames 7,9-9 mm compr., anteras elípticas, 0,4-0,7 mm compr.; ovário elíptico, raro assimétrico, seríceo, subséssil, glândulas puntiformes amarelas ausentes sob o indumento, estilete filiforme, glabro, estigma 0,1-0,2 mm compr. Legume reto, oblongo, não constricto entre as sementes, base obtusa, ápice agudo, mucronado, marrom-escuro, alvo- ou argênteo-seríceo, glândulas puntiformes amarelas presentes, 1,3-1,8 × 0,6-0,7 cm; sementes suborbiculares, marrom-claras, marmoreadas, 3,3-4,3 × 3,5-4,2 mm compr.; hilo oblongo, 1,2-1,4 mm compr.; funículo inserido no centro do hilo. 


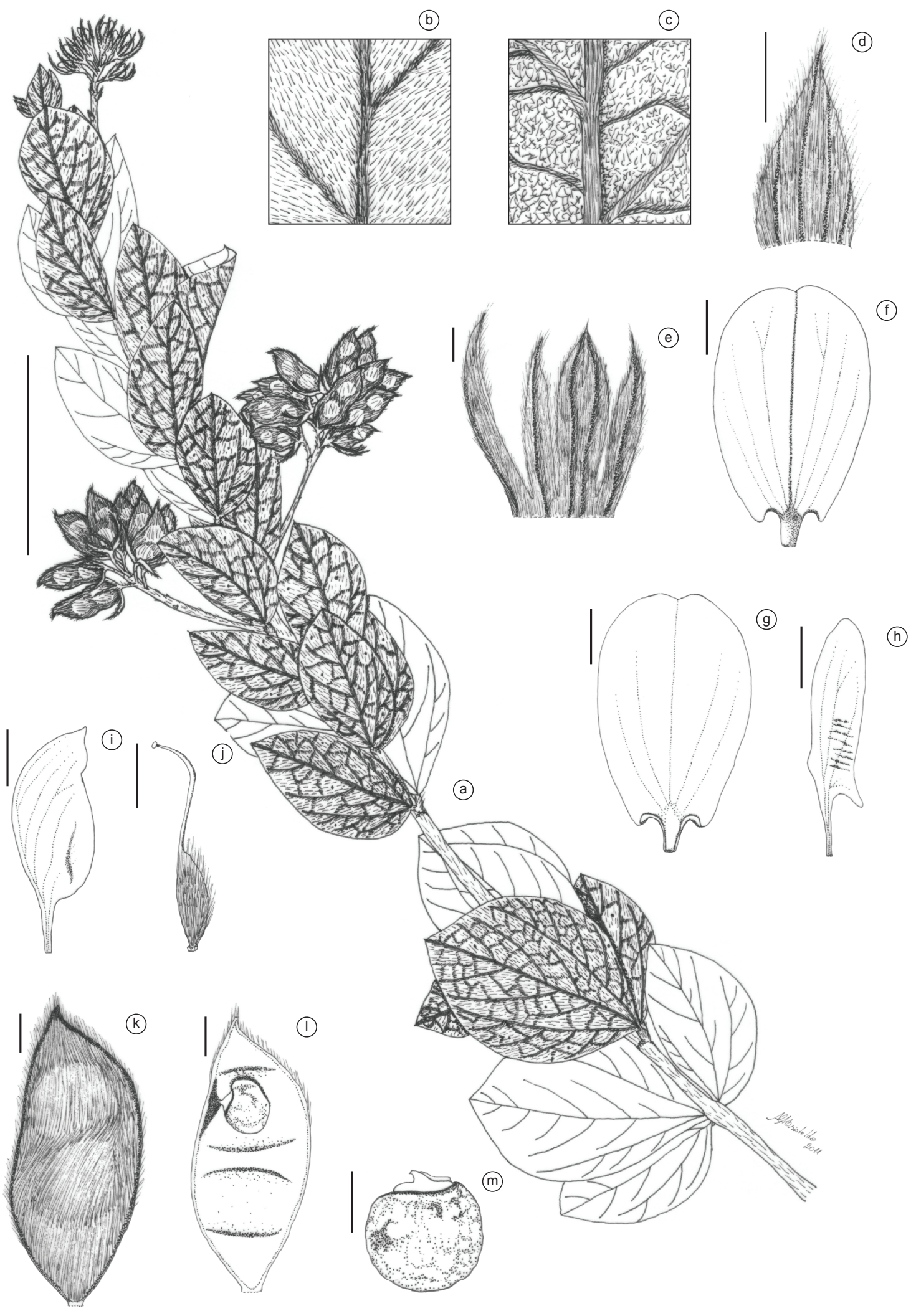

Figura 6. Rhynchosia leucophylla Benth.: a) ramo com flores e frutos; b) detalhe do indumento da face adaxial do folíolo; c) detalhe do indumento da face abaxial do folíolo; d) estípula; e) cálice; f) face externa do estandarte; g) face interna do estandarte; h) asa; i) pétala da quilha; j) gineceu; k) fruto; 1) fruto aberto; m) semente (Pott 13693; Pott 13735; Pott 10490). As escalas foram de $5 \mathrm{~cm}$ compr. para os ramos com flores e frutos, $1 \mathrm{~cm}$ compr. para detalhe do folíolo e $2 \mathrm{~mm}$ para as estruturas florais, fruto e estípula.

Figure 6. Rhynchosia leucophylla Benth.: a) branches with flowers and fruits; b) detail of the indumentum of adaxial leaflet surface; c) detail of the indumentum of abaxial leaflet surface; d) stipule; e) calyx; f) external face of the standard; g) internal face of the standard; h) wing; i) keel petal; j) gynoecium; k) fruit; 1) open fruit; m) seed (Pott 13693; Pott 13735; Pott 10490). The scales were $5 \mathrm{~cm}$ length for branches with flowers and fruit, $1 \mathrm{~cm}$ length for detail of leaflets and $2 \mathrm{~mm}$ for floral structure, fruit and stipule. 
Material examinado: BRASIL. Mato Grosso do Sul: Bonito, 08/XI/2002, fl. fr., Pott et al. 10490 (CGMS); 08/XI/2002, fl. fr., Pott et al. 10524 (CGMS); 09/XII/2005, fl., Pott 13762 (CGMS); 11/ XII/2005, fl. fr., Pott \& Pott 13693 (CGMS); Dourados, 24/I/1979, fr., Saturnino 422 (PAMG); 16/V/1976, fl. fr., Hatschbach 38.687 (MBM); Maracaju, 03/II/1952, fr., Kuhlmann s.n. (SP 69923); 29/ XII/1973, fl., Sucre 10563 (RB); Porto Murtinho, 08/XII/2005, fl., Pott 13735 (CGMS); Rio Brilhante, 16/II/1970, fl. fr., Hatschbach 23.623 (MBM); Sidrolândia, 23/I/1971, fl., Hatschbach 25.055 (MBM).

Rhynchosia leucophylla caracteriza-se pelo hábito subarbustivo ereto, pelas folhas curto-pecioladas, argênteo-tomentosas ou seríceas. Assemelha-se a $R$. corylifolia quando apresenta folíolos orbiculares ou suborbiculares, mas se diferencia pelos pecíolos e ráquis foliar subsésseis (menores que $2 \mathrm{~mm}$ compr.), pelo hábito subarbustivo ereto, pelo indumento argênteo e pela ausência de tricomas glandulares de base bulbosa nos frutos. Rhynchosia leucophylla é, muitas vezes, identificada erroneamente como Eriosema, pelo hábito ereto e por apresentar folhas curto-pecioladas, mas a forma oblonga do hilo, a inserção central do funículo no hilo, além do cálice com o lacínio vexilar fundido parcialmente ao lateral são características suficientes para distinção entre os gêneros.

Distribuição geográfica e ambiente - leste do Paraguai e Brasil: MS, SP (Bentham 1859, Grear 1978, Fortunato 2012). Ocorre apenas no oeste e sul do estado de Mato Grosso do Sul, em savana (cerrado), savana parque (campo cerrado), savana gramíneo lenhosa (campo arbustivo de cerrado), na transição entre campo limpo e pastagem cultivada em área de cerradão decidual, sobre solos argilosos ou litólicos com afloramento calcário.

Floresce nos meses de janeiro, fevereiro, maio, novembro e dezembro; frutifica em janeiro, fevereiro, maio, novembro e dezembro.

\section{Rhynchosia melanocarpa Grear, Mem. New York Bot. Gard. 31(1): 43. 1978 (Figura 7)}

Trepadeiras 2-5 m compr.; ramos amarelados ou alvacentos, tomentosos, esparso-tomentosos, tricomas glandulares de base bulbosa e glândulas puntiformes amarelas presentes. Estípulas caducas, ovadas, base truncada, ápice acuminado, externamente alvo-tomentosas, glândulas puntiformes amarelas ausentes, internamente glabras, 2,5-3,4 × 0,9-1,4 mm; um par de estipelas filiformes bastante evidentes na base do folíolo apical e um par nos folíolos laterais, 2-4,6 mm compr., tomentosas. Pecíolos 1,5$6,3 \mathrm{~cm}$ compr., ráquis foliar 1-3,1 cm compr., tomentosos, esparsotomentosos, tricomas glandulares de base bulbosa e glândulas puntiformes amarelas presentes. Folíolos discolores, não bulados, face adaxial alvo-pubescente, tomentosa, tricomas glandulares de base bulbosa esparsos, face abaxial alvo-tomentosa, glândulas puntiformes amarelas presentes; folíolos apicais rômbicos, 3,3-8,7 $\times$ 2-7,6 cm; laterais assimétricos, rômbicos ou trulados, 2,8-7,7 × 1,8-4,8 cm; ápice agudo ou acuminado, mucronado, base cuneada ou atenuada. Racemos ou panículas 8,6-21,1 cm compr., laxifloros, 20-40 flores por racemo, pedúnculos alvo-tomentosos, tricomas glandulares de base bulbosa e glândulas puntiformes amarelas esparsas. Pedicelos 1,9-4,4 mm compr., tomentosos, tricomas glandulares de base bulbosa e glândulas puntiformes amarelas esparsas; brácteas tomentosas, glândulas puntiformes amarelas raramente presentes, 2,7-3,3 × 0,5-1 $\mathrm{mm}$; cálice externamente tomentoso, glândulas puntiformes amarelas e tricomas glandulares de base bulbosa esparsos, internamente esparso-seríceos, 4,7-5,8 mm compr., lacínio carenal 2,8-4 mm compr., os demais $1,8-2,5 \mathrm{~mm}$ compr.; corola 7-7,5 mm compr.; estandarte obovado, largo-obovado, externamente pubescente, glândulas puntiformes amarelas e tricomas glandulares de base bulbosa presentes, sem calosidade evidente, aurículas estreitas, ápice retuso ou obtuso, 7-7,6 × 4,5-5 mm, unguícula 0,9-1,2 mm compr.; asas estreito-oblongas, glabras, glândulas puntiformes amarelas ausentes, esculturas na região ínfero-mediana, uniauriculadas, ápice obtuso, base obliquamente hastada, 5,8-6,4 × 0,9-1,4 mm, unguícula 1,4-1,5 mm compr.; pétalas da quilha largo-elípticas, falcadas, estreito-obovadas, glabras ou externamente pubérulas no ápice e no bordo, glândulas puntiformes amarelas presentes, cuculadas na região mediano-basal, ápice obtuso a levemente rostrado, base atenuada, obliquamente hastada, 6,3-7,2 × 2,1-2,7 mm, unguícula 1,3-1,6 mm compr.; estames 5,8$7 \mathrm{~mm}$ compr., anteras oblongas, elípticas, $0,4-0,5 \mathrm{~mm}$ compr.; ovário oblongo, elíptico assimétrico, seríceo, tomentoso, subséssil, glândulas puntiformes amarelas abundantes sob o indumento, estilete filiforme, esparso-tomentoso na base, estigma 0,1-0,2 mm compr. Legume reto, oblongo, constricto entre as sementes, base cuneada, ápice agudo, mucronado, vináceo ou preto-vináceo, esparso-tomentoso, glândulas puntiformes amarelas presentes, 1,6-2,2 × 0,4-0,6 cm; sementes suborbiculares, bicolores (pretas ou marrom-escuras com área hilar vermelha), 3,7-3,9 × 4,7-5,2 mm compr.; hilo oblongo ou elíptico, 1,2-1,4 mm compr.; funículo inserido no centro do hilo.

Material examinado: BRASIL. Mato Grosso do Sul: Caarapó, 23/V/1978, fr., Allem \& Vieira 1986 (HUEFS); Campo Grande, 31/ VII/1999, fr., Motta s.n. (CGMS10069); 12/VII/1969, fr., Hatschbach \& Guimarães 21.836 (MBM); 30/IV/2007, fl., Salomão et al. 260 (CGMS); 03/VIII/2007, fr., Assunção et al. 25 (CGMS); 28/ VIII/2007, fl., Cristaldo 182 (CGMS); 04/IX/2007, fl. fr., Cristaldo \& Alves 183 (CGMS); 19/IX/1990, fr., Resende 232 (CGMS); 10/X/2007, fl., Salomão et al. 82 (CGMS); 19/X/2007, fr., Cristaldo 191 (CGMS); Selvíria, 30/VII/1991, fr., Tiritan 72 (HRCB, RB); 27/ VIII/1991, fr., Tiritan \& Paiva 725 (RB).

Rhynchosia melanocarpa caracteriza-se pelos folíolos rômbicos, pelas estipelas filiformes, nítidas à vista desarmada, pelos frutos constrictos, de coloração vinácea, e pelas sementes bicolores, pretas ou marrom-escuras, com uma área vermelha circundando o hilo. Pode ser confundida com $R$. minima devido às estipelas filiformes e a forma dos folíolos, diferenciando-se, no entanto, pela ausência de glândulas puntiformes na face adaxial dos folíolos, pela presença de tricomas glandulares de base bulbosa e de estrias vináceas no estandarte. Rhynchosia melanocarpa é afim a $R$. phaseoloides (Swartz) DC., $R$. naineckensis Fortunato e $R$. pyramidalis (Lam.) Urban. $R$. phaseoloides, com ocorrência desde o Caribe até o Sul da América do Sul, diferencia-se pela ausência de estipelas e pelas sementes bicolores, metade vermelhas e metade pretas; $R$. naineckensis, com distribuição no Brasil, Paraguai e norte da Argentina, apresenta folíolos concolores e inflorescência não ramificada; e $R$. pyramidalis, além de ocorrer apenas na América Central, possui sementes quase inteiramente vermelhas, exceto por uma pequena área preta na base da semente (Grear 1978, Fortunato 1982, 1983).

Distribuição geográfica e ambiente - Argentina, Bolívia, Paraguai, Venezuela e Brasil: AM, CE, DF, MA, MT, MG, PA, PR, RJ, SP (Grear 1978, Fortunato 1983, 2012), MS. Rhynchosia melanocarpa é encontrada no nordeste, centro e sul do estado de Mato Grosso do Sul, em áreas de savana (cerrado), transição floresta ripária-savana (mata de galeria-cerrado), floresta semidecídua e borda de mata degradada, em solos argilosos, litólicos ou hidromórficos.

Floresce nos meses de abril e agosto a outubro; frutifica em maio e de julho a outubro.

\section{Rhynchosia minima (L.) DC., Prodr. 2: 385. 1825 (Figura 8)}

Trepadeiras; ramos amarelados ou alvacentos, glabrescentes a pubescentes, esparso-tomentosos, tricomas glandulares de base 


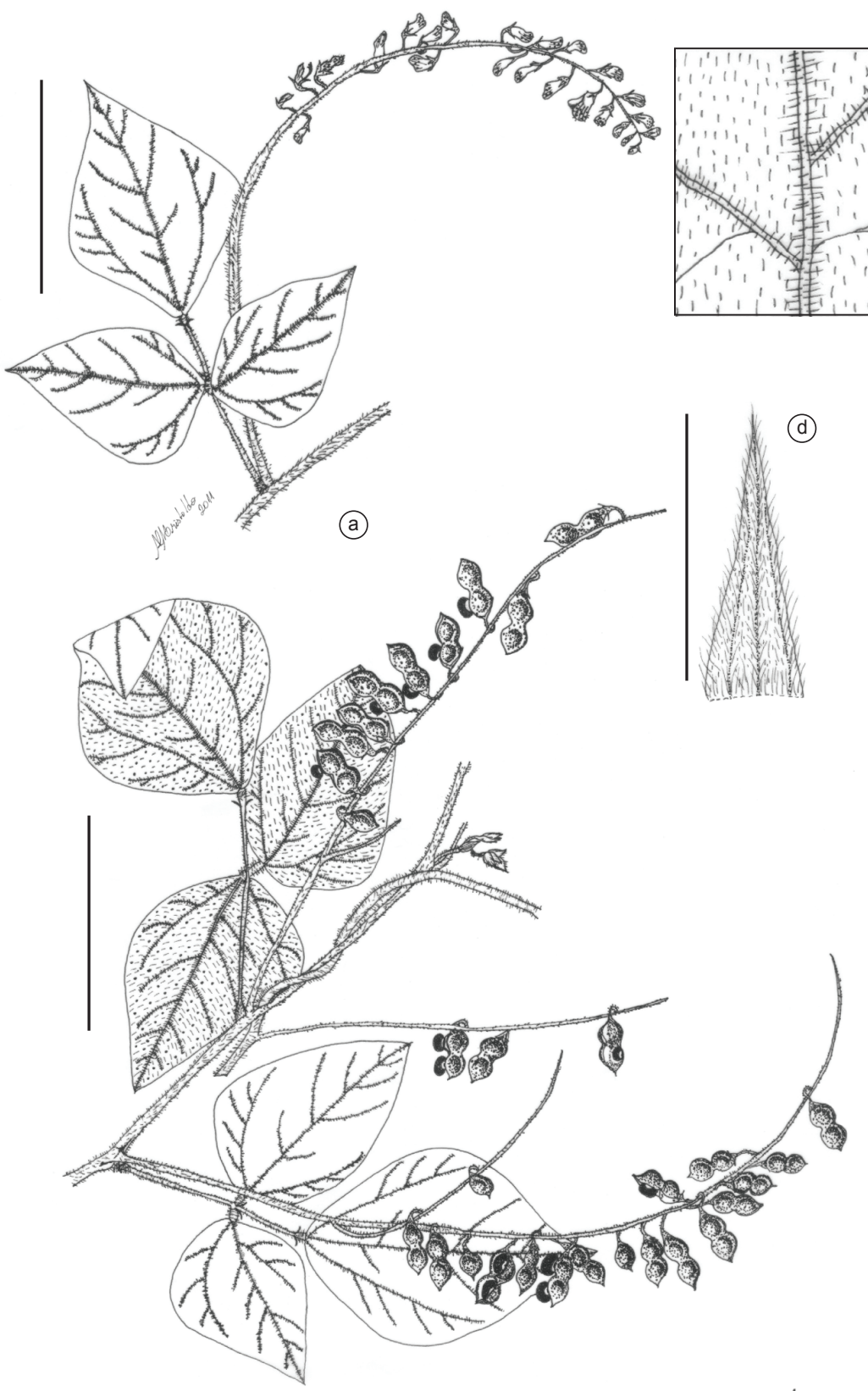

(b)

(c)
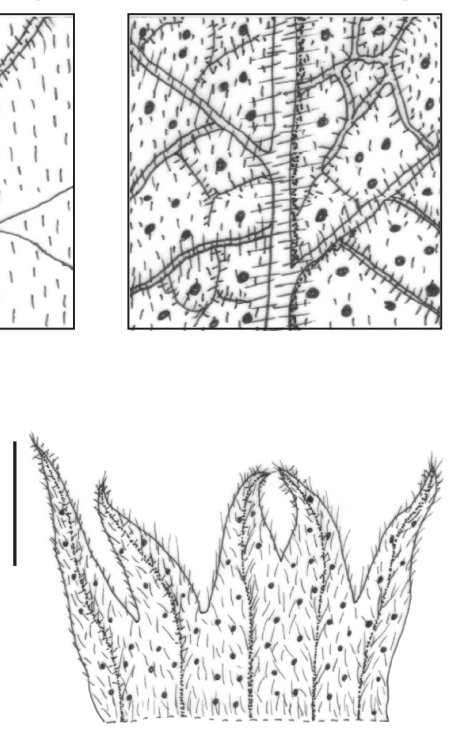

(e)
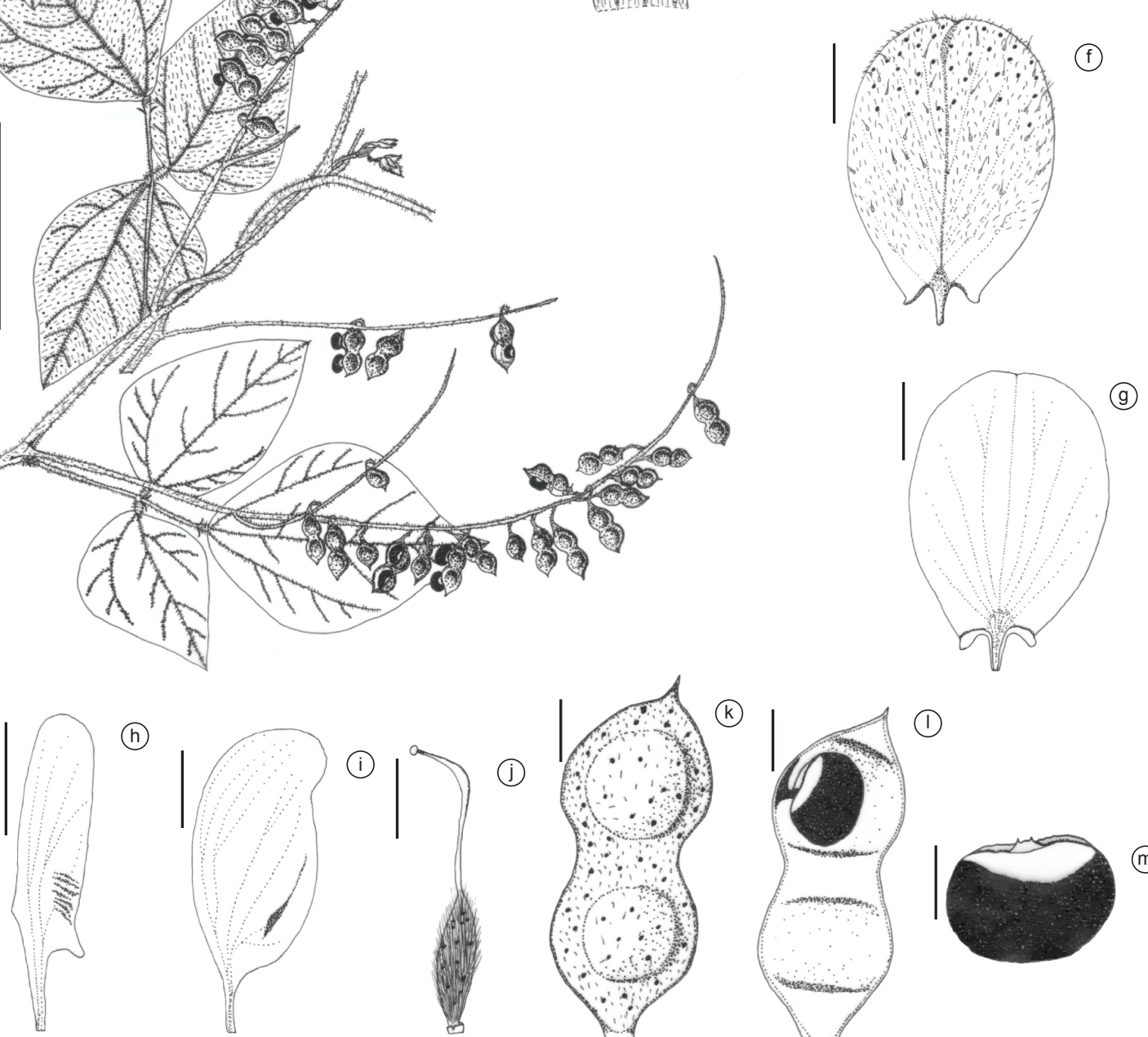

(h)

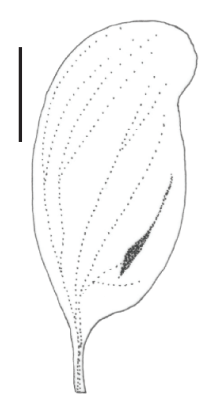

(i)

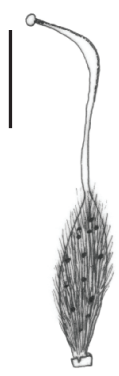

(i)

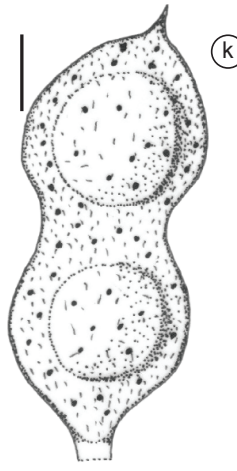

(

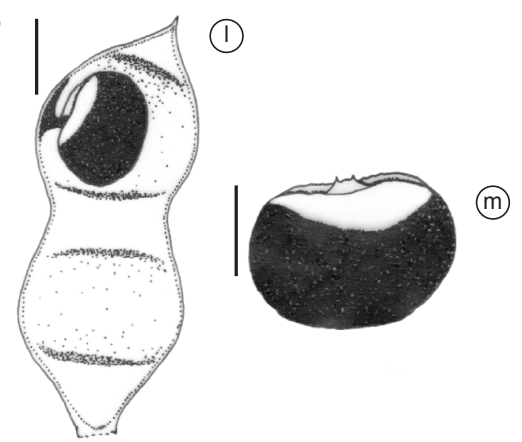

Figura 7. R. melanocarpa Grear: a) ramo com flores e frutos; b) detalhe do indumento da face adaxial do folíolo; c) detalhe do indumento da face abaxial do folíolo; d) estípula; e) cálice; f) face externa do estandarte; g) face interna do estandarte; h) asa; i) pétala da quilha; j) gineceu; k) fruto; l) fruto aberto; m) semente (Cristaldo 183; Salomão 82; Cristaldo 191). As escalas foram de $5 \mathrm{~cm}$ compr. para os ramos com flores e frutos, $1 \mathrm{~cm}$ compr. para detalhe do folíolo e $2 \mathrm{~mm}$ para as estruturas florais, fruto e estípula.

Figure 7. R. melanocarpa Grear: a) branches with flowers and fruits; b) detail of the indumentum of adaxial leaflet surface; c) detail of the indumentum of abaxial leaflet surface; d) stipule; e) calyx; f) external face of the standard; g) internal face of the standard; h) wing; i) keel petal; j) gynoecium; k) fruit; 1) open fruit; $\mathrm{m}$ ) seed (Cristaldo 183; Salomão 82; Cristaldo 191). The scales were $5 \mathrm{~cm}$ length for branches with flowers and fruit, $1 \mathrm{~cm}$ length for detail of leaflets and $2 \mathrm{~mm}$ for floral structure, fruit and stipule. 


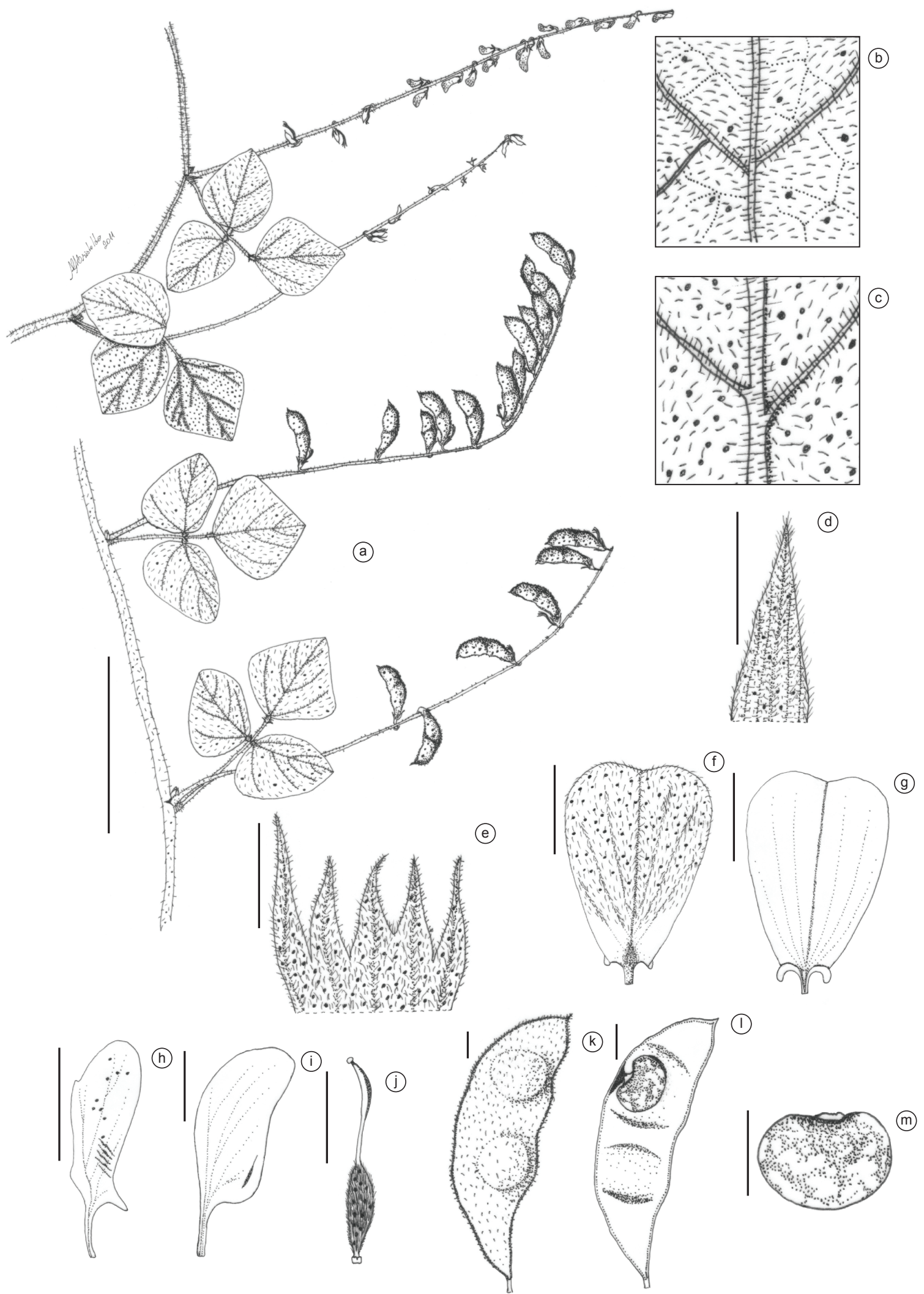

Figura 8. R. minima (L.) DC.: a) ramo com flores e frutos; b) detalhe do indumento da face adaxial do folíolo; c) detalhe do indumento da face abaxial do folíolo; d) estípula; e) cálice; f) face externa do estandarte; g) face interna do estandarte; h) asa; i) pétala da quilha; j) gineceu; k) fruto; 1) fruto aberto; m) semente (Cristaldo 167 e 176; Nunes 201A). As escalas foram de $5 \mathrm{~cm}$ compr. para os ramos com flores e frutos, $1 \mathrm{~cm}$ compr. para detalhe do folíolo e $2 \mathrm{~mm}$ para as estruturas florais, fruto e estípula.

Figure 8. R. minima (L.) DC.: a) branches with flowers and fruits; b) detail of the indumentum of adaxial leaflet surface; c) detail of the indumentum of abaxial leaflet surface; d) stipule; e) calyx; f) external face of the standard; g) internal face of the standard; h) wing; i) keel petal; j) gynoecium; k) fruit; l) open fruit; m) seed (Cristaldo 167 e 176; Nunes 201A). The scales were $5 \mathrm{~cm}$ length for branches with flowers and fruit, $1 \mathrm{~cm}$ length for detail of leaflets and $2 \mathrm{~mm}$ for floral structure, fruit and stipule. 
bulbosa ausentes, glândulas puntiformes amarelas ou castanhas abundantes. Estípulas caducas, ovadas, base truncada, ápice acuminado, alvo-tomentosas, externamente pubescentes, glândulas puntiformes amarelas esparsas ou ausentes, internamente glabras, 2,0 $\times 0,6 \mathrm{~mm}$; um par de estipelas filiformes na base do folíolo apical e um par nos folíolos laterais, 0,5-1,7 mm compr., pubescentes. Pecíolos 1,2-3,7 cm compr., ráquis foliar 0,1-1,0 cm compr., pubescentes, esparso-tomentosos, glândulas puntiformes amarelas ou castanhas presentes. Folíolos geralmente concolores, não bulados, face adaxial alvo-pubescente, esparso-serícea, face abaxial alvo-pubescente, tomentosa; glândulas puntiformes amarelas, castanhas presentes em ambas as faces, abundantes na face abaxial; folíolos apicais rômbicos, $1,1-3,8 \times 1,0-3,7 \mathrm{~cm}$; laterais assimétricos, rômbicos ou trulados, 1,0-3,2 × 1,0-2,7 cm; ápice obtuso ou agudo, mucronado, base obtusa ou cuneada. Racemos 3,1-19,2 compr., laxifloros, 10-24 flores por racemo, pedúnculos alvacentos, esparso-tomentosos, glândulas puntiformes amarelas, castanhas presentes. Pedicelos 1,2-1,3 mm compr., esparso-tomentosos, glândulas puntiformes amarelas, castanhas presentes; brácteas externamente tomentosas, glândulas puntiformes amarelas presentes, 1,8-1,9 × 0,2-0,5 mm; cálice externamente pubescente, tomentoso, glândulas puntiformes amarelas presentes, internamente esparso-seríceo, 3,1-4,0 mm compr., lacínio carenal 1,8-2,4 mm compr., os demais 1,6-1,9 mm compr.; corola 5,16,7 mm compr.; estandarte obovado, largo-obovado, externamente pubescente, glândulas puntiformes amarelas presentes, sem calosidade evidente, aurículas estreitas, ápice retuso ou truncado, 4,5-6,4 $\times$ 3,3-4,3 mm, unguícula 0,6-1,1 mm compr.; asas estreito-obovadas, oblongas-assimétricas, glabras, glândulas puntiformes amarelas esparsas na região súpero-mediana, esculturas na região ínferomediana, uniauriculadas, ápice obtuso, base obliquamente hastada, 3,5-5,3 × 0,9-1,4 mm, unguícula 0,9-1,4 mm compr.; pétalas da quilha oblongo-falcadas, glabras, glândulas puntiformes amarelas ausentes, levemente cuculadas na região basal, ápice obtuso ou levemente rostrado, base obliquamente hastada, 4,2-5,9 × 1,4-1,8 mm, unguícula 1,0-1,6 mm compr.; estames 3,8-6,0 mm compr., anteras elípticas, 0,3-0,4 mm compr.; ovário elíptico, seríceo, subséssil, glândulas puntiformes amarelas abundantes sob o indumento, estilete filiforme, glabro, estigma 0,1-0,2 mm compr. Legume falcado, não constricto entre as sementes, base cuneada, ápice obtuso, mucronado, marrom, esparso-tomentoso, glândulas puntiformes amarelas abundantes sob o indumento, 1,5-1,8 $\times 0,4-0,5 \mathrm{~cm}$; sementes reniformes, marrons, marrom-vináceas, marmoreadas, 2,4-2,6 × 2,7-3,6 mm compr.; hilo elíptico, 0,9-1,1 mm compr.; funículo inserido no centro do hilo.

Material examinado: BRASIL. Mato Grosso do Sul: Aquidauana, 19/III/2003, fl., Hatschbach et al. 74.912 (MBM); Bodoquena, 15/V/2002, fl. fr., Hatschbach et al. 72.959 (MBM); Corumbá, 18/IV/1983, fl. fr., Conceição 1386 (CGMS, COR); 10/ IV/1985, fl., Pott 149 (CGMS); 11/IV/1992, fr., Resende et al. 688 (CGMS); 30/IV/1997, fl., Caroline \& Letícia 3 (COR); 21/VII/1999, fl., Costa 26 (COR); 15/IX/2001, fl., Lima et al. 31 (COR); VII/2006, fl. fr., Cristaldo et al. 167 (CGMS); 30/XI/2006, fr., Alves 233 (CGMS); Miranda, 05/VI/1973, fl. fr., Silva 117 (SP); 08/VI/1973, fl. fr., Silva 151 (SP); 26/X/1978, fl. fr., Allem et al. 2173 (HUEFS); 24/X/1988, fl., Hatschbach et al. 52.589 (MBM); 13/V/1976, fl., Hatschbach 38.652 (MBM); Porto Murtinho, 14/IV/2005, fl., Nunes et al. 154 (CGMS); 15/IV/2005, fl., Nunes et al. 201A (CGMS); 15/IV/2005, fl. fr., Noguchi et al. 209 (CGMS).

Rhynchosia minima caracteriza-se pelo hábito volúvel, pelos folíolos rômbicos, glândulas puntiformes amarelas ou castanhas em ambas as faces dos folíolos e pelos frutos falcados. Pode ser confundida com $R$. edulis e $R$. melanocarpa quando coletada apenas a parte vegetativa ou na ausência de frutos. Rhynchosia edulis apresenta folíolos rômbicos ou trulados, glândulas puntiformes castanhas ou pretas apenas na face abaxial dos folíolos, tricomas glandulares de base bulbosa em ambas as faces dos folíolos e frutos retos. Rhynchosia melanocarpa é uma trepadeira, com folíolos rômbicos ou trulados, glândulas puntiformes amarelas apenas na face abaxial dos folíolos, tricomas glandulares de base bulbosa esparsos na face adaxial e frutos constrictos entre as sementes. Rhynchosia minima distingue-se destas, no entanto, pela presença de glândulas puntiformes amarelas ou castanhas em ambas as faces dos folíolos, pelas flores geralmente menores e sem estrias avermelhadas ou vináceas e ausência de tricomas glandulares de base bulbosa.

Rhynchosia minima é a espécie mais amplamente distribuída dentro do gênero, ocorrendo desde o Velho Mundo até o continente americano onde é a mais coletada por ocorrer geralmente em áreas perturbadas, sendo considerada uma planta ruderal (Grear 1978).

Distribuição geográfica e ambiente - desde o sul dos Estados Unidos até a Argentina e Brasil: BA, CE, MA, MG, PA, SP (Fortunato 1983, 2012, Grear 1978, S.T.S. Miotto, dados não publicados), MS. Espécie encontrada apenas na borda oeste do estado de Mato Grosso do Sul, no Pantanal, nas sub-regiões do Paraguai, Miranda e Nabileque, em borda de floresta estacional semidecidual (mata calcária), floresta ripária (mata inundável e ciliar), savana estépica arborizada (Chaco) e beira de estradas, em solos calcários, arenosos ou argilosos.

Floresce nos meses de março a julho, setembro e outubro; frutifica de abril a julho e em novembro.

\section{Agradecimentos}

Os autores agradecem aos curadores dos herbários CGMS, COR, HRCB, HUEFS, IBGE, PAMG, MBM, RB, R e SP pelo empréstimo das exsicatas e a CAPES e FUNDECT (Fundação de Apoio ao Desenvolvimento de Ensino, Ciência e Tecnologia do Estado de Mato Grosso do Sul) pela concessão da bolsa de mestrado à primeira autora.

\section{Referências Bibliográficas}

BENTHAM, G. 1859. Leguminosae. Phaseoleae. Rhynchosia. In Flora Brasiliensis (C.F.P. Martius, ed.). F. Fleischer, Lipsiae, v.15, part 1, p.200-206.

DUBS, B. 1998. Prodromus Florae Matogrossensis - The Botany of Mato Grosso. Küssnacht: Betrona-Verlag, Series B, n.3.

FONT-QUER, P. 1953. Diccionario de botánica. Labor S.A., Barcelona.

FORTUNATO, R.H. 1982. Uma nueva espécie del género Rhynchosia (Leguminosae). Darwiniana 24(1-4):497-501.

FORTUNATO, R.H. 1983. Sinopsis de las Especies Argentinas del Genero Rhynchosia. Parodiana 2(1):25-58.

FORTUNATO, R.H. 2000. Systematic relationship in Rhynchosia (CajaninaePhaseoleae-Papilionoideae-Fabaceae) from neotropics. In Advances in Legume Systematics 9 (P.S. Herendeen and A. Bruneau, ed.). Royal Botanic Gardens, Kew, p.339-354.

FORTUNATO, R.H. 2012. Rhynchosia. In Lista de Espécies da Flora do Brasil. Jardim Botânico do Rio de Janeiro, Rio de Janeiro. http://floradobrasil. jbrj.gov.br/2012/FB115228 (último acesso em 25/março/2012).

GONÇALVES, E.G. \& LORENZI, H. 2007. Morfologia Vegetal: organografia e dicionário ilustrado de morfologia de plantas vasculares. Instituto Plantarum de Estudos da Flora, São Paulo.

GREAR, J.W. 1970. A Revision of the American Species of Eriosema (Leguminosae-Lotoideae). Mem. New York Bot. Gard. 20(3):1-98.

GREAR, J.W. 1978. A Revision of the New World Species of Rhynchosia (Leguminosae-Faboideae). Mem. New York Bot. Gard. 31(1):1-170.

GUEDES-BRUNI, R.R., MORIM, M.P., LIMA, H.C. \& SYLVESTRE, L.S. 2002. Inventário Florístico. In Manual Metodológico para Estudos Botânicos na Mata Atlântica (L.S. Sylvestre \& M.M.T. Rosa, orgs.). Seropédica, Rio de Janeiro, p.24-49. 
HARRIS, J.G. \& HARRIS, M.W. 1994. Plant Identification Terminology: An Illustrated Glossary. Spring Lake Publishing, Utah.

INSTITUTOBRASILEIRO DE GEOGRAFIAEESTATÍSTICA-IBGE. 1992. Manual Técnico da Vegetação Brasileira. Fundação Instituto Brasileiro de Geografia e Estatística, Rio de Janeiro.

LACKEY, J.A. 1981. Phaseoleae DC. In Advances in Legume Systematics 1 (R.M. Polhill \& P.H. Raven, eds.). Royal Botanic Gardens, Kew, p.347-354.

LEWIS, G.P. 1987. Legumes of Bahia. Royal Botanic Gardens, Kew.

MIOTTO, S.T.S. 1988. Leguminosae-Faboideae Tribo Phaseoleae Subtribo Cajaninae. - Flora Ilustrada do Rio Grande do Sul. Bol. Inst. Biocienc. Univ. Fed. Rio Gd. Sul (43):1-88.

NUNES, G.P. 2006. Estudo Florístico de Formações Chaquenhas Brasileiras e Caracterização Estrutural de um Remanescente de Chaco de Porto Murtinho, MS, Brasil. Dissertação de mestrado, Universidade Federal de Mato Grosso do Sul, Campo Grande.

POTT, A. \& POTT, V.J. 1994. Plantas do Pantanal. Embrapa, Brasília.

POTT, A. \& POTT, V.J. 1999. Flora do Pantanal - Listagem atual de fanerógamas. In Simpósio sobre Recursos Naturais Sócio-econômicos do Pantanal. Embrapa Pantanal, Corumbá, p.297-325.

POTT, A. \& POTT, V.J. 2003. Espécies de Fragmentos Florestais em Mato Grosso do Sul. In Fragmentação florestal e Alternativas de Desenvolvimento rural na Região Centro-Oeste (R.B. Costa, org.). UCDB, Campo Grande, p.26-52.
RADFORD, A.E., DICKSON, W.C., MASSEY, J.R. \& BELL, C.R. 1974. Vascular Plant Systematics. Harper \& Row, New York.

RIBEIRO, J.F. \& WALTER, B.M.T. 1998. Fisionomias do bioma Cerrado. In Cerrado: ambiente e flora (S.M. Sano. \& S.P. Almeida, eds.). Embrapa, Planaltina, p. 89-166.

RIZZINI, C.T. 1977. Sistematização Terminológica da Folha. Rodriguésia 29(42):103-125.

ROGALSKI, L.D. \& MIOTTO, S.T.S. 2011. O gênero Rhynchosia Lour. (Leguminosae-Papilionoideae) nos estados do Paraná e Santa Catarina, Brasil. Rev. Bras. Bioci. 9(3):332-349.

SANO, S.M., ALMEIDA, S.P. \& RIBEIRO, J.F. 2008. Cerrado: Ecologia e Flora. Embrapa Informação Tecnológica, Brasília, v.2.

SCHRIRE, B.D. 2005. Tribo Phaseoleae. In Legumes of the World (G. Lewis, B. Schrire, B. Mackinder \& M. Lock, eds.). Plants People Possibilites, Kew, p.393-431.

STEARN, W.T. 2004. Botanical Latin (David \& Chales, eds.). Timber Press. Portland, Oregon.

STIRTON, C.H. 1981. Petal Sculpturing in Papilionoideae Legumes. In Advances in Legume Systematics (R.M. Polhill \& P.H. Raven, eds.). Crown Copyright, Kew, v.1, p.771-788.

THIERS, B. 2012. Index Herbariorum: a global directory of public herbaria and associated staff. New York Botanical Garden's Virtual Herbarium. http://sweetgum.nybg.org/ih/> (último acesso em: 12/01/2012).

Recebido em 11/04/2012

Versão reformulada recebida em 29/09/2012

Publicado em 15/10/2012 